\title{
Rapid Tyrosine Phosphorylation of Neuronal Proteins Including Tau and Focal Adhesion Kinase in Response to Amyloid- $\beta$ Peptide Exposure: Involvement of Src Family Protein Kinases
}

\author{
Ritchie Williamson, ${ }^{1}$ Timothy Scales, ${ }^{1}$ Bruce R. Clark, ${ }^{1}$ Graham Gibb, ${ }^{1}$ C. Hugh Reynolds, ${ }^{1}$ Stuart Kellie, ${ }^{3}$ \\ Ian N. Bird, ${ }^{3}$ Ian M. Varndell, ${ }^{4}$ Paul W. Sheppard, ${ }^{4}$ Ian Everall, ${ }^{2}$ and Brian H. Anderton ${ }^{1}$ \\ Department of ${ }^{1}$ Neuroscience, ${ }^{2}$ Section of Experimental Neuropathology and Psychiatry, Institute of Psychiatry, King's \\ College London, London SE5 8AF, United Kingdom, 3Yamanouchi Research Institute, Littlemore Park, Oxford OX4 4SX, \\ United Kingdom, and ${ }^{4}$ Affiniti Research Products Limited, Mamhead Castle, Mamhead, Exeter EX6 8HD, United Kingdom
}

The increased production of amyloid $\beta$-peptide $(\mathrm{A} \beta)$ in Alzheimer's disease is acknowledged to be a key pathogenic event. In this study, we examined the response of primary human and rat brain cortical cultures to $\mathrm{A} \beta$ administration and found a marked increase in the tyrosine phosphorylation content of numerous neuronal proteins, including tau and putative microtubuleassociated protein 2c (MAP2c). We also found that paired helical filaments of aggregated and hyperphosphorylated tau are tyrosine phosphorylated, indicating that changes in the phosphotyrosine content of cytoplasmic proteins in response to $A \beta$ are potentially an important process. Increased tyrosine phosphorylation of cytoskeletal and other neuronal proteins was specific to fibrillar $\mathrm{A} \beta_{25-35}$ and $\mathrm{A} \beta_{1-42}$. The tyrosine phosphorylation was blocked by addition of the Src family tyrosine kinase inhibitor 4-amino-5-(4chlorophenyl)-7(t-butyl)pyrazol(3,4-D)pyramide (PP2) and the phosphatidylinositol 3-kinase inhibitor LY 294002. Tyrosine phosphorylation of tau and MAP2c was concomitant with an increase in the tyrosine phosphorylation and subsequent putative activation of the non-receptor kinase, focal adhesion kinase (FAK). Immunoprecipitation of Fyn, a member of the Src family, from $\mathrm{A} \beta_{25-35}$-treated neurons showed an increased association of Fyn with FAK. A $\beta$ treatment of cells also stimulated the sustained activation of extracellular regulated kinase-2, which was blocked by addition of PP2 and LY 294002, suggesting that FAK/Fyn/PI3-kinase association is upstream of mitogenactivated protein (MAP) kinase signaling in $A \beta$-treated neurons. This cascade of signaling events contains the earliest biochemical changes in neurons to be described in response to $A \beta$ exposure and may be critical for subsequent neurodegenerative changes.

Key words: Alzheimer's disease; amyloid $\beta$-peptide; cortical neurons; tyrosine phosphorylation; FAK; Fyn; ERK2; tau; MAP2C
Neurofibrillary tangles and senile neuritic plaques with an extracellular core of amyloid are the pathological lesions in the brain in Alzheimer's disease (Smith and Anderton, 1994). Although deposition of amyloid $\beta$-peptide $(\mathrm{A} \beta)$ is an early event as Alzheimer's disease (AD) develops, it is not clear how tangles subsequently form. Neurofibrillary tangles are composed of paired helical filaments of aggregated and hyperphosphorylated tau (PHF-tau) (Lovestone et al., 1994; Hanger et al., 1998). Several laboratories have reported that $\mathrm{A} \beta$ treatment of neurons in primary culture results in an elevation in tau phosphorylation, indicative of a link between $\mathrm{A} \beta$ deposition and tau pathology (Busciglio et al., 1995).

In these previous studies, changes in the phosphorylation state of tau were usually observed after prolonged exposure to $\mathrm{A} \beta$. The protein kinases implicated in phosphorylating tau in response to $\mathrm{A} \beta$ treatment include the extracellular regulated kinase-1

Received July 25, 2001; revised Oct. 10, 2001; accepted Oct. 10, 2001.

This work was supported by grants from the Down's Syndrome Association, the Alzheimer's Society, the Wellcome Trust, the Medical Research Council, and Yamanouchi Research Institute. We are grateful to J. Parsons and M. I. Samuel from King's College Hospital for provision of human fetal tissue. We also thank The London Neurodegenerative Disease Brain Bank, Department of Neuropathology, Institute of Psychiatry, for providing postmortem brain tissue, and P. Davies for providing PHF-1 antibody.

Correspondence should be addressed to Ritchie Williamson, King's College London, Institute of Psychiatry, Department of Neuroscience, De Crespigny Park, Denmark Hill, London SE5 8AF, UK. E-mail: r.williamson@iop.kcl.ac.uk Copyright (C) 2001 Society for Neuroscience $0270-6474 / 01 / 220010-11 \$ 15.00 / 0$
(ERK1) and ERK2 (McDonald et al., 1998; Pyo et al., 1998; Rapoport and Ferreira, 2000), cyclin-dependent kinase-5 (Imahori and Uchida, 1997; A. Alvarez et al., 1999; Lee et al., 2000), and glycogen synthase kinase- $3 \alpha$ and $-3 \beta$ (GSK-3 $\alpha$ and $-3 \beta$ ) (Takashima et al., 1998). Other studies of the effects of $\mathrm{A} \beta$ on cells have shown that certain parameters are affected within shorter periods. These include activation of the protein tyrosine kinase (PTK) Lyn in microglial cells (McDonald et al., 1998), increased tyrosine phosphorylation and $\mathrm{Ca}^{2+}$ influx (Luo et al., 1995), activation of phosphatidylinositol 3-kinase (PI3-kinase) (Luo et al., 1996), cAMP response element-binding protein phosphorylation (Sato et al., 1997), increased oxidative stress (Ekinci et al., 2000), and finally apoptosis (Harada and Sugimoto, 1999).

The tyrosine kinase Fyn is upregulated in a subset of neurons in AD brain that also contain hyperphosphorylated tau (Shirazi and Wood, 1993). Fyn knock-out mice display specific neurological deficits (Grant et al., 1992), and brain slices from Fyn knockout mice are completely protected from $\mathrm{A} \beta$-derived diffusible ligand (ADDL) toxicity (Lambert et al., 1998). Fyn is associated with tyrosine phosphorylated tau in neuronal cells, and Fyn may activate the serine/threonine kinase, GSK-3 $\beta$, a tau kinase that can hyperphosphorylate tau (Lee et al., 1998; Lesort et al., 1999).

Here we report that treatment of primary human and rat cortical neuronal cultures with fibrillar $\mathrm{A} \beta$ resulted in a rapid increase in the overall tyrosine phosphorylation of several cellular proteins, including tau and most probably the microtubule- 
associated protein 2c (MAP2c). The increased tyrosine phosphorylation was specific to treatment with aggregated $\mathrm{A} \beta$ and was blocked by addition of the Src family tyrosine kinase inhibitor 4-amino-5-(4-chlorophenyl)-7(t-butyl)pyrazol(3,4-D)pyramide (PP2). Increased phosphorylation of focal adhesion kinase (FAK) on tyrosine was also observed after $\mathrm{A} \beta$ treatment, and immunoprecipitation of Fyn from $A \beta$-treated neurons showed an increase in association of Fyn with FAK. Concomitant with these rapid changes in tyrosine phosphorylation of cellular proteins, $\mathrm{A} \beta$ treatment also activated ERK2. The rapid changes in FAK/Fyn and tau tyrosine phosphorylation reported here may be critical early pathogenic events initiated by $\mathrm{A} \beta$. Furthermore, because the tyrosine phosphorylation changes preceded neuronal death by many hours, $\mathrm{A} \beta$ stimulation of these signaling events is likely to be a rapid event but with long-term effects.

\section{MATERIALS AND METHODS}

All chemicals were purchased from Sigma (Gillingham, UK), unless otherwise stated. The Src family kinase inhibitor PP2, the PI3-kinase inhibitors wortmannin and LY 294002, and the MEK activation inhibitor PD 98059 were obtained from Calbiochem (Nottingham, UK). The $\mathrm{A} \beta$-derived peptide comprising amino acids $25-35\left(\mathrm{~A} \beta_{25-35}\right)$, the reverse sequence 35-25 (A $\left.\beta_{35-25}\right)$, and 1-42 $\left(\mathrm{A} \beta_{1-42}\right)$ were obtained from Bachem (Essex, UK). $A \beta_{25-35}$ and $A \beta_{35-25}$ were resuspended in sterile distilled $\mathrm{H}_{2} \mathrm{O}$ at a concentration of $2 \mathrm{mM}$ and incubated at $37^{\circ} \mathrm{C}$ for $1 \mathrm{hr}$ to allow fibril formation (Terzi et al., 1994). $\mathrm{A} \beta_{1-42}$ was resuspended in $50 \%(\mathrm{v} / \mathrm{v}) \mathrm{PBS} /$ sterile distilled $\mathrm{H}_{2} \mathrm{O}$ at a concentration of $1.5 \mathrm{mg} / \mathrm{ml}$ and incubated at $37^{\circ} \mathrm{C}$ for $7 \mathrm{~d}$ to allow fibril formation (Serpell, 2000). Soluble $\mathrm{A} \beta_{25-35}$ was prepared immediately before use by resuspending $\mathrm{A} \beta_{25-35}$ in sterile $\mathrm{H}_{2} \mathrm{O}$ at a concentration of $1 \mathrm{mg} / \mathrm{ml}$. Anti-phospho-ERK monoclonal antibody $(\mathrm{mAb})$ was obtained from New England Biolabs (Hitchin, $\mathrm{UK})$. Anti-ERK polyclonal antibody (pAb) and anti-Fyn mAb were obtained from Transduction Laboratories (Lexington, KY). AntiMAP2c mAb HM-2 was obtained from Sigma. Anti-phosphotyrosine mAb 4G10 was obtained from Upstate Biotechnology (Lake Placid, NY). Anti-FAK pAb C20 was obtained from Santa Cruz Biotechnology (Santa Cruz, CA). Protein A/G Plus was obtained from Autogen Bioclear (Wiltshire, UK). mAb PHF-1 was provided by Dr. P. Davies (Department of Pathology, Albert Einstein College of Medicine, Bronx, NY). SHP-1 tyrosine phosphatase was cloned and expressed by one of our collaborating laboratories. Horseradish peroxidase (HRP)-conjugated donkey anti-rabbit and sheep anti-mouse Igs were obtained from Amersham Pharmacia (Buckinghamshire, UK).

Primary cortical neuronal cultures. Neuronal cultures were prepared from embryonic day 18 rat embryos as described previously (Davis et al., 1995). Essentially, embryos were removed, and their fetal brain cortices were dissected and freed of meninges. The cells were dissociated by trypsinization $\left[0.25 \%(\mathrm{v} / \mathrm{v})\right.$ for $20 \mathrm{~min}$ at $\left.37^{\circ} \mathrm{C}\right]$. Trypsinization was stopped by washing three times in Neurobasal medium (Life Technologies, Paisley, UK) containing 10\% (v/v) fetal calf serum (FCS) (Autogen Bioclear) and then treated with 2 Kunitz $\mathrm{U} / \mathrm{ml}$ deoxyribonuclease 1 followed by trituration with fire-polished Pasteur pipettes. Primary rat brain cortical cells $\left(2 \times 10^{5}\right)$ were plated onto poly-L-lysine $(10 \mu \mathrm{g} / \mathrm{ml})$ coated glass coverslips in 12 -well tissue culture plates, or $4 \times 10^{6}$ neurons were plated into $25 \mathrm{~cm}^{2}$ flasks (Marathon, Harrow, UK) and maintained in Neurobasal medium containing B27 supplement (Life Technologies), $2 \mathrm{~mm}$ glutamine, and $20 \mu \mathrm{g} / \mathrm{ml}$ gentamycin solution. Rat brain primary cells were cultured for $7 \mathrm{~d}$ before being used for the treatments described. Primary human brain neuronal cultures were established from terminations of pregnancy at 14-20 week gestation through collaboration with King's College Hospital, Ethical Committee approval No. 1997-0037. Brain cortices were identified on the basis of their large size and presence of convolutions (immature gyri). Cell dissociation and culture procedures were essentially identical for rat and human tissue except that human cells were plated onto poly-L-lysine $(10 \mu \mathrm{g} / \mathrm{ml})$-coated and lami$\operatorname{nin}(5 \mu \mathrm{g} / \mathrm{ml})$-coated glass coverslips in 12-well tissue culture plates or into $25 \mathrm{~cm}^{2}$ flasks. Cells were cultured for $14 \mathrm{~d}$ to allow them to attain a fully polarized and mature phenotype similar to 7-d-old rat brain primary cells (our unpublished observations), with a change of medium every third day before they were used for the treatments described.

Cell treatments. Cells were treated with the appropriate peptide for the indicated times in culture medium. In some instances cells were pre- treated with $30 \mu \mathrm{M}$ PP2 for $18 \mathrm{hr}, 20 \mu \mathrm{M}$ PD 98059 for 45 min, $100 \mu \mathrm{M} \mathrm{LY}$ 294002 for $15 \mathrm{~min}, 100 \mathrm{nM}$ wortmannin for $15 \mathrm{~min}, 10 \mu \mathrm{M}$ bisindolylmaleimide for $45 \mathrm{~min}$, or $25 \mathrm{~mm} \mathrm{LiCl}$ for $4 \mathrm{hr}$.

Enrichment of PHF-tau from AD brain. Gray matter from an AD brain was obtained from The London Neurodegenerative Diseases Brain Bank (Department of Neuropathology, Institute of Psychiatry) and handhomogenized in a glass Dounce homogenizer in ice-cold Buffer A [100 mM 2-(morpholino)ethanesulfonic acid (MES), $\mathrm{pH} 6.5,0.5 \mathrm{mM} \mathrm{MgCl}_{2}, 1$ mM EGTA, $1 \mathrm{~m} \mathrm{NaCl}, 50 \mathrm{~mm}$ D- $N$-acetylglucosamine, $50 \mathrm{~mm}$ imidazole, $25 \mathrm{~mm} \beta$-glycerophosphate, $20 \mathrm{~mm} \mathrm{NaF}, 10 \mathrm{~mm} \mathrm{Na}$ pyrophosphate, and $0.5 \mathrm{~mm}$ PMSF], using $4 \mathrm{ml}$ Buffer A per gram of tissue. Insoluble material was removed from the homogenate by centrifugation at $27,000 \times g$ (average) at $4^{\circ} \mathrm{C}$ for $30 \mathrm{~min}$. The pellet was discarded, and the supernatant was centrifuged at $95,000 \times g$ at $4^{\circ} \mathrm{C}$ for $2 \mathrm{hr}$. The resulting pellet was resuspended in Buffer B (10 mm Tris- $\mathrm{HCl}, \mathrm{pH} 7.4,4$ m guanidine- $\mathrm{HCl}$, $10 \mathrm{~mm}$ DTT, $50 \mathrm{~mm}$ D- $N$-acetylglucosamine, $50 \mathrm{~mm}$ imidazole, $25 \mathrm{~mm}$ $\beta$-glycerophosphate, $20 \mathrm{~mm} \mathrm{NaF}, 10 \mathrm{~mm} \mathrm{Na}$ pyrophosphate, and $0.5 \mathrm{~mm}$ PMSF), using $0.5 \mathrm{ml}$ Buffer B per gram of starting material for $2 \mathrm{hr}$ at room temperature. The resulting suspension was centrif uged at 95,000 $\times$ $g$ (average) at $4^{\circ} \mathrm{C}$ for $1 \mathrm{hr}$. The supernatant was retained and dialyzed overnight at $4^{\circ} \mathrm{C}$ against 81 of Buffer $\mathrm{C} \mathrm{(20} \mathrm{mM} \mathrm{bis-Tris-propane,} \mathrm{pH} 7.0$, and $1 \mathrm{mM}$ DTT) before centrif ugation at $95,000 \times g$ (average) at $4^{\circ} \mathrm{C}$ for $1 \mathrm{hr}$. The resultant supernatant was boiled for $10 \mathrm{~min}$, then cooled on ice and centrifuged at $95,000 \times g$ (average) at $4^{\circ} \mathrm{C}$ for $1 \mathrm{hr}$. The final supernatant was used for SDS-PAGE and Western blotting.

Western blotting, tyrosine phosphatase treatment, and immunoprecipitations. Cells were washed three times in ice-cold TBS ( 25 mM Tris, pH 8.0, $140 \mathrm{~mm} \mathrm{NaCl}$, and $5 \mathrm{~mm} \mathrm{KCl}$ ) and lysed by scraping into ice-cold radioimmunoprecipitation assay (RIPA) buffer $[1 \%(\mathrm{v} / \mathrm{v})$ Triton, $0.1 \%$ (w/v) SDS, 0.5\% (w/v) deoxycholate, $20 \mathrm{~mm}$ Tris, pH 7.4, $150 \mathrm{~mm} \mathrm{NaCl}$, $10 \mathrm{~mm} \mathrm{NaF}, 1 \mathrm{~mm} \mathrm{Na} \mathrm{VO}_{4}, 1 \mathrm{~mm}$ EDTA, $1 \mathrm{~mm}$ EGTA, and $0.2 \mathrm{~mm}$ PMSF] and left to stand for $20 \mathrm{~min}$ on ice. Insoluble material was removed by centrifugation at $15,800 \times g$ (average) at $4^{\circ} \mathrm{C}$ for $10 \mathrm{~min}$. Heat-stable fractions were prepared by scraping cells into ice-cold TBS and centrifuging at $15,800 \times g$ (average) at $4^{\circ} \mathrm{C}$ for $10 \mathrm{~min}$. The supernatant was discarded, and the pellet was resuspended in $100 \mu \mathrm{l}$ MES/ $\mathrm{NaCl}$ buffer (100 mm MES, $1 \mathrm{~m} \mathrm{NaCl}, 0.5 \mathrm{~mm} \mathrm{MgCl}$, 1 mM EGTA, $2 \mathrm{~mm}$ DTT, $1 \mathrm{~mm} \mathrm{Na}_{3} \mathrm{VO}_{4}, 1 \mathrm{~mm}$ benzamidine hydrochloride, $5 \mu \mathrm{g} / \mathrm{ml}$ leupeptin, $2 \mu \mathrm{g} / \mathrm{ml}$ aprotinin, $1 \mu \mathrm{g} / \mathrm{ml}$ pepstatin, $0.2 \mathrm{~mm}$ PMSF) and immediately heated to $100^{\circ} \mathrm{C}$ for 10 min followed by cooling by immersing in ice and then centrifuged at $15,800 \times g$ (average) at $4^{\circ} \mathrm{C}$ for $25 \mathrm{~min}$. The supernatant that was enriched in tau and MAP2c was retained. Protein concentrations were quantified by the method of Bradford (1976). Before electrophoresis, samples were mixed with equal volumes of $2 \times$ SDSPAGE sample buffer (Sigma), heated to $100^{\circ} \mathrm{C}$ for $5 \mathrm{~min}$, and then centrifuged at $15,800 \times g$ (average) for $5 \mathrm{~min}$. Proteins were resolved by SDS-PAGE using $10 \%(\mathrm{w} / \mathrm{v})$ polyacrylamide. Proteins were transferred to nitrocellulose (Schleicher \& Scheull, Dassel, Germany) and submerged in blocking buffer TBS-Tween [TBS containing $0.2 \%(\mathrm{v} / \mathrm{v})$ Tween 20 and 3\% (w/v) nonfat dried milk] for $1 \mathrm{hr}$ at room temperature. Blots were incubated with primary antibody diluted in blocking buffer overnight at $4^{\circ} \mathrm{C}$. Blots were washed three times in PBS-Tween and incubated with HRP-linked secondary antibodies diluted in blocking buffer for $1 \mathrm{hr}$. After an additional three washes in TBS-Tween, antibody binding was detected by an enhanced chemiluminescence (ECL) system (Amersham Pharmacia).

For phosphotyrosine antibody detection, blocking buffer and primary antibody buffer contained $4 \%(\mathrm{w} / \mathrm{v})$ BSA instead of $3 \%(\mathrm{w} / \mathrm{v})$ nonfat dried milk. To reprobe blots, nitrocellulose was stripped by washing in $100 \mathrm{~mm}$ 2-mercaptoethanol, 2\% (w/v) SDS, $62.5 \mathrm{~mm}$ Tris-HCl, pH 6.7, for $30 \mathrm{~min}$ at $50^{\circ} \mathrm{C}$ with occasional agitation. For tyrosine phosphatase treatment, total cell lysates from primary cortical cultures were resolved by SDS-PAGE followed by transfer of proteins to nitrocellulose and subsequent blocking in blocking buffer for $1 \mathrm{hr}$ at room temperature. Blots were then incubated for $2 \mathrm{hr}$ in $0.1 \%$ (v/v) 2-mercaptoethanol, 50 $\mathrm{mm}$ Tris-HCl, $\mathrm{pH}$ 6.7, containing $8.6 \mu \mathrm{g} / \mathrm{ml}$ His-tagged full-length SHP-1 for $2 \mathrm{hr}$ at room temperature with occasional agitation.

Immunoprecipitations were performed by incubation of cell lysates (400 $\mu \mathrm{g}$ total protein) with $1 \mu \mathrm{g}$ primary antibody for $2 \mathrm{hr}$ at $4^{\circ} \mathrm{C}$ followed by addition of $20 \mu \mathrm{l}$ protein A/G PLUS-Agarose and a further incubation of $1.5 \mathrm{hr}$ at $4^{\circ} \mathrm{C}$. The mixture was then centrifuged at $15,800 \times g$ (average) at $4^{\circ} \mathrm{C}$ for $5 \mathrm{~min}$, and the supernatant was removed at $4^{\circ} \mathrm{C}$ until analysis. The beads were washed four times in ice-cold RIPA buffer. After the final wash, the beads were resuspended in $40 \mu$ l SDS-PAGE 


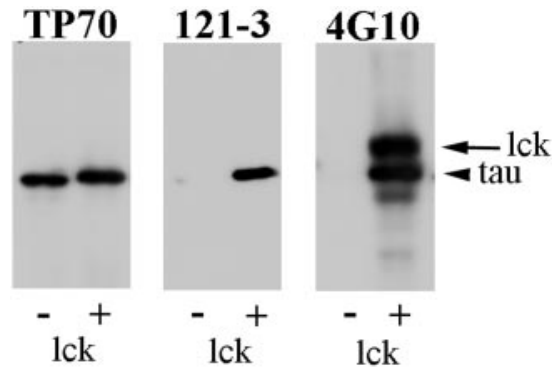

Figure 1. Characterization of tyrosine-phosphorylated tau-specific antibody 121-3. Western blots of 2N4R recombinant tau that was either unphosphorylated $(-)$ or phosphorylated $(+)$ by lck were probed with the antibodies TP70, 121-3, and 4G10 as indicated. Arrowhead indicates the tau band; arrow indicates the lck band.

sample buffer, heated to $100^{\circ} \mathrm{C}$ for $10 \mathrm{~min}$, resolved by $7.5 \%(\mathrm{w} / \mathrm{v})$ polyacrylamide SDS-PAGE, and Western blotted as described above.

Characterization of tyrosine phosphorylated tau antibody. The $\mathrm{pAb}$ 121-3 was raised in rabbit to a synthetic tyrosine phosphorylated peptide of tau corresponding to residues 21-36 of human tau [largest isoform with two N-terminal inserts and four C-terminal repeats (2N4R)] and so recognizes tau when it is phosphorylated at $\mathrm{Tyr}_{29}$. The specificity of the 121-3 antibody was tested on $2 \mathrm{~N} 4 \mathrm{R}$ recombinant tau that was either unphosphorylated or phosphorylated on tyrosine residues as follows: $5 \mu \mathrm{l}$ $(24 \mu \mathrm{g})$ of $2 \mathrm{~N} 4 \mathrm{R}$ recombinant tau was added to $51 \mu \mathrm{l}$ reaction mixture (50 mM Tris- $\mathrm{HCl}$, pH 7.5, $1 \mathrm{~mm}$ ATP, $10 \mathrm{~mm} \mathrm{MgCl}_{2}, 5 \mathrm{~mm} \mathrm{MnCl}_{2}, 0.1$ mM EDTA, $10 \mu \mathrm{M} \mathrm{Na} \mathrm{VO}_{4}$, and $1 \mathrm{~mm}$ DTT) and incubated in the presence (for phosphorylation) or absence (control, unphosphorylated) of $4 \mu \mathrm{llck}$ at $30^{\circ} \mathrm{C}$ for $2 \mathrm{hr}$. The reaction was stopped by addition of $2 \times$ SDS-PAGE sample buffer and heating to $100^{\circ} \mathrm{C}$ for $5 \mathrm{~min}$. Unphosphorylated or phosphorylated tau $(0.4 \mu \mathrm{g})$ was resolved by SDS-PAGE using $10 \%(\mathrm{w} / \mathrm{v})$ polyacrylamide, transferred to nitrocellulose, and probed with antibodies TP70, 4G10, and $121-3$ as described previously. Figure 1 shows that both the 4G10 and 121-3 antibodies were specific for the tyrosine-phosphorylated tau and did not react with tau that was not phosphorylated. The phosphorylated tau displays a slightly reduced electrophoretic mobility compared with the unphosphorylated tau as detected by TP70 because of its increased phosphorylation. The lck band is labeled by the 4G10 antibody because of autophosphorylation.

Immunofluorescence microscopy. Cultures were fixed in $4 \%$ (w/v) paraformaldehyde (PFA) for $30 \mathrm{~min}$ at room temperature, permeablized with $0.2 \%(\mathrm{v} / \mathrm{v})$ Triton X-100 in TBS for $10 \mathrm{~min}$, and blocked in $5 \%(\mathrm{v} / \mathrm{v})$ FCS $/ 0.2 \%(\mathrm{w} / \mathrm{v})$ Tween 20 in TBS for $30 \mathrm{~min}$. Primary antibody was diluted in blocking solution and incubated for $1 \mathrm{hr}$. FAK and Fyn were detected by a monoclonal antibody to Fyn, referred to here as anti-Fyn, and by C-20, a polyclonal antibody to FAK. Primary antibodies were detected using goat anti-mouse or goat anti-rabbit Igs coupled to Oregon Green or Texas Red (Molecular Probes, Eugene, OR), and the slides were mounted in Vectashield (Vector Labs, Burlingame, CA). Cells were analyzed using a Zeiss Axioscop microscope at $40 \times$ magnification, and images were captured via a CCD camera (Princeton Instruments, Marlow, UK).

Caspase activation. Caspase activation was measured using a CASPATAG kit (Intergen Company, Oxford, UK) comprising a carboxyfluorescein (FAM) derivative of benzyloxycarbonylvalylalanylaspartic acid fluoromethyl ketone (zVAD-FMK), which is a potent inhibitor of the caspase activity. The FAM-VAD-FM K binds irreversibly to activated caspase- $1,-3,-4,-5,-7,-8$. FAM-VAD-FMK was added to the neuronal cultures and incubated at $37^{\circ} \mathrm{C}$ for $1 \mathrm{hr}$. Hoechst stain $(200$ $\mu \mathrm{g} / \mathrm{ml}$ ) was added (1:500 dilution) for $5 \mathrm{~min}$, and the cells were washed twice in TBS and fixed in $4 \%(\mathrm{w} / \mathrm{v})$ PFA for $30 \mathrm{~min}$ at room temperature; the slides were mounted in Vectashield.

Cell viability. Primary rat neuronal cells were cultured in 96-well tissue culture plates and grown for $7 \mathrm{~d}$. After $7 \mathrm{~d}$ in culture, media was replaced, and the cells were treated with $\mathrm{A} \beta$ peptides. Lactate dehydrogenase (LDH) release was assayed using the Cytotox 96 assay kit (Promega UK Ltd., Southampton, UK). Total LDH release was determined by treatment of cultures with $0.9 \%$ (v/v) Triton X-100 for 45 min. Fifty microliters from each well were transferred to a 96-well plate and mixed with $50 \mu \mathrm{l}$ substrate mix. After $30 \mathrm{~min}$ incubation at room temperature, the reaction was stopped by adding $50 \mu \mathrm{l}$ stop solution. Absorbance was read at $492 \mathrm{~nm}$ using a Bio-Tek microplate reader.

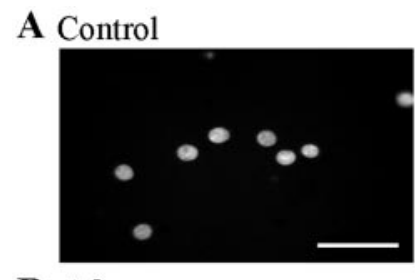

B $\mathrm{A} \beta$

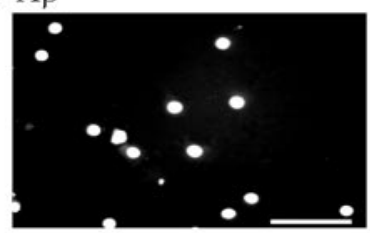

C Control

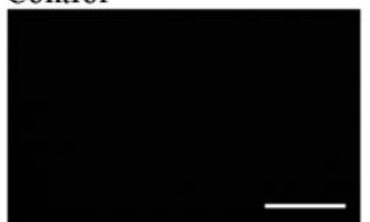

D $\mathrm{A} \beta$

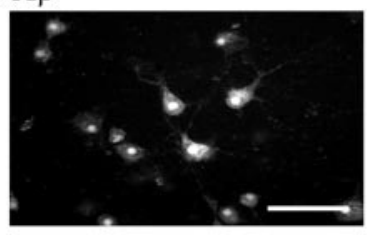

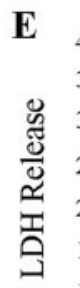

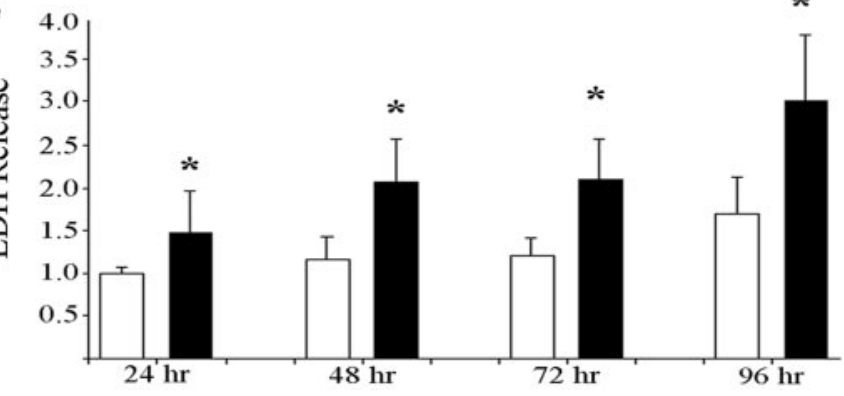

Figure 2. A $\beta$-induced neuronal death of primary rat cortical cultures. $A$, $B$, Hoechst nuclear labeling and immunolabeling $(C, D)$ of activated caspases in untreated control cultures $(A, C)$ and $\mathrm{A} \beta_{25-35}$-treated cultures $(10 \mu \mathrm{M}, 48 \mathrm{hr})(B, D)$ of 7-d-old primary rat cortical cultures. Scale bars, $50 \mu \mathrm{M} . E, \mathrm{LDH}$ release from control $(\square)$ cultures and cultures treated $(\square)$ with $\mathrm{A} \beta_{25-35}(10 \mu \mathrm{M} ; 24 h r, 48 h r, 72 h r, 96 h r)$, expressed as fold increase in LDH release over control LDH release after $24 \mathrm{hr}$, normalized to 1 . Error bars indicate SDs based on three independent experiments, 15 readings per experiment. * $p<0.0001$; Mann-Whitney $U$ test.

Densitometry and image analysis. Film images from ECL-developed Western blots developed for different times to ensure linearity of exposure were analyzed with a GS710 scanning densitometer using the Quantity One (Bio-Rad, Hemel Hempstead, UK) quantification software.

\section{RESULTS}

\section{$A \beta$ activates caspases during the neurotoxic response of rat and human fetal brain neurons}

To establish conditions of $\mathrm{A} \beta$ neurotoxicity, $\mathrm{A} \beta_{25-35}$ was aged to produce aggregated $\mathrm{A} \beta_{25-35}$ and applied to rat or human primary neuronal cultures in Neurobasal medium either with or without supplements. Cells were stained for activated caspases after exposure to $\mathrm{A} \beta_{25-35}$ for different times, and cell lysis was monitored by release of LDH. Typical results after different exposure times to $\mathrm{A} \beta$ are illustrated in Figure 2. The earliest time at which caspase activation and LDH release could be observed was $\sim 24$ $\mathrm{hr}$ and was maximal at $96 \mathrm{hr}$. The 3-(4,5-dimethylthiazol-2-yl)-5(3-carboxymethoxyphenyl)-2-(4-sulfophenyl)-2H-tetrazolium, inner salt (MTS) assay was also used to monitor neurotoxicity and showed a reduction of $30 \%$ of the ability of the cells to reduce MTS after $24 \mathrm{hr}$ of $\mathrm{A} \beta_{25-35}$ treatment and was complete at $72 \mathrm{hr}$ (data not shown). The reverse sequence $\mathrm{A} \beta_{35-25}$ induced no detectable cell death by the LDH or MTS assays, and the presence or absence of B27 supplement did not affect the neurotoxic response. All subsequent experiments were thereafter performed in Neurobasal medium supplemented with B27. 
A
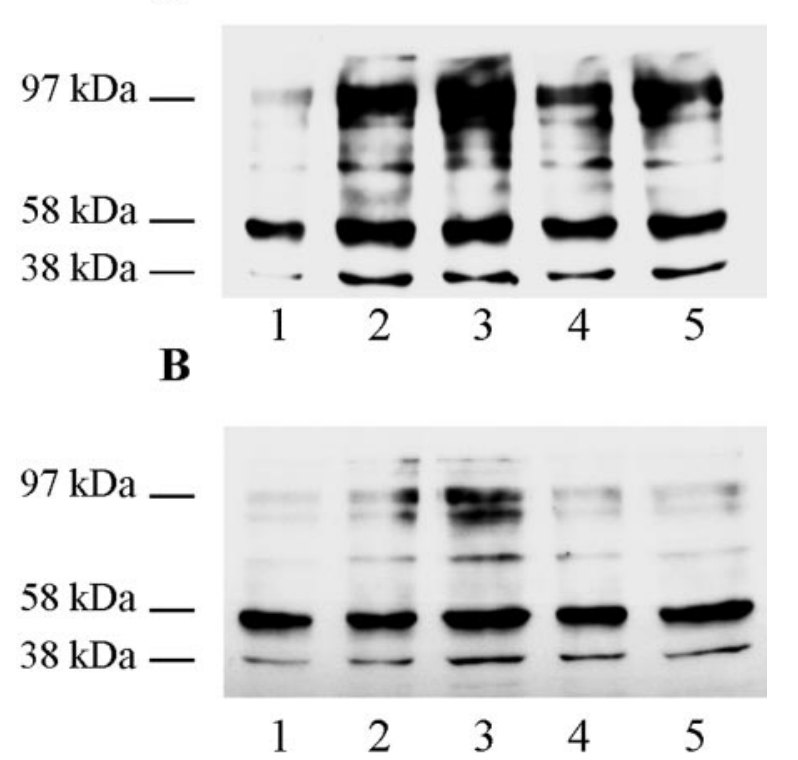

Figure 3. $\mathrm{A} \beta$-induced tyrosine phosphorylation of neuronal proteins. Rat primary cortical neurons $(A)(7 \mathrm{~d}$ in culture) and human primary cortical neurons $(B)\left(14 \mathrm{~d}\right.$ in culture) were treated with $10 \mu \mathrm{M} \mathrm{A} \beta_{25-35}$ as follows: lane 1, control (no $\mathrm{A} \beta_{25-35}$ ); lane 2, 1 min; lane 3, 2 min; lane 4, $5 \mathrm{~min}$; lane 5, $10 \mathrm{~min}$. Whole-cell lysates were prepared, and Western blots were probed with anti-phosphotyrosine antibody 4G10. Apparent molecular mass $(k D a)$ markers are indicated to the left.

\section{A $\beta$ treatment induces a rapid elevation of tyrosine phosphorylation of numerous neuronal proteins}

To identify possible early cellular responses to $\mathrm{A} \beta$ treatment that precede measurable cell death, changes in phosphotyrosine content of neuronal proteins were investigated because tyrosine phosphorylation is often an early signaling event. Total cell lysates analyzed by Western blotting with the phosphotyrosinespecific monoclonal antibody $4 \mathrm{G} 10$ showed that exposure of rat neuronal cultures to $\mathrm{A} \beta_{25-35}$ resulted in a rapid increase in the phosphotyrosine content of numerous proteins (Fig. $3 A$ ). There was an increase in the tyrosine phosphorylation content of at least eight bands ranging between relative molecular masses of 38 and $120 \mathrm{kDa}$. The increase in phosphotyrosine content of all of these proteins was already very marked after 1 min exposure to $\mathrm{A} \beta_{25-35}$ but was partially transient, peaking at $2 \mathrm{~min}$ after exposure and declining thereafter.

Similar patterns of changes were obtained for total cell lysates of $\mathrm{A} \beta$-treated primary human brain cortical cultures (Fig. $3 B$ ). There was an increase in tyrosine phosphorylation of approximately seven or eight bands. Again, the increase in the phosphotyrosine content of most of these proteins was marked after $1 \mathrm{~min}$ A $\beta$ treatment and peaked at 2 min after exposure. However, unlike the primary rat cortical cultures, the phosphotyrosine content of these proteins had declined to control untreated levels by $10 \mathrm{~min}$ after exposure. Treatment of primary rat neuronal cultures with soluble $\mathrm{A} \beta_{25-35}$ did not result in an increase in the phosphotyrosine content of any proteins (data not shown).

Exposure of rat neuronal cultures to the full-length fibrillar $\mathrm{A} \beta$ peptide, $\mathrm{A} \beta_{1-42}$, also resulted in an increase in the phosphotyrosine content of neuronal proteins, although in this experiment the peak was somewhat delayed to $\sim 5 \mathrm{~min}$, and the increase in phosphotyrosine content was less marked than in $\mathrm{A} \beta_{25-35}$-treated cultures (Fig. 4A). Tyrosine phosphatase treatment of the blot
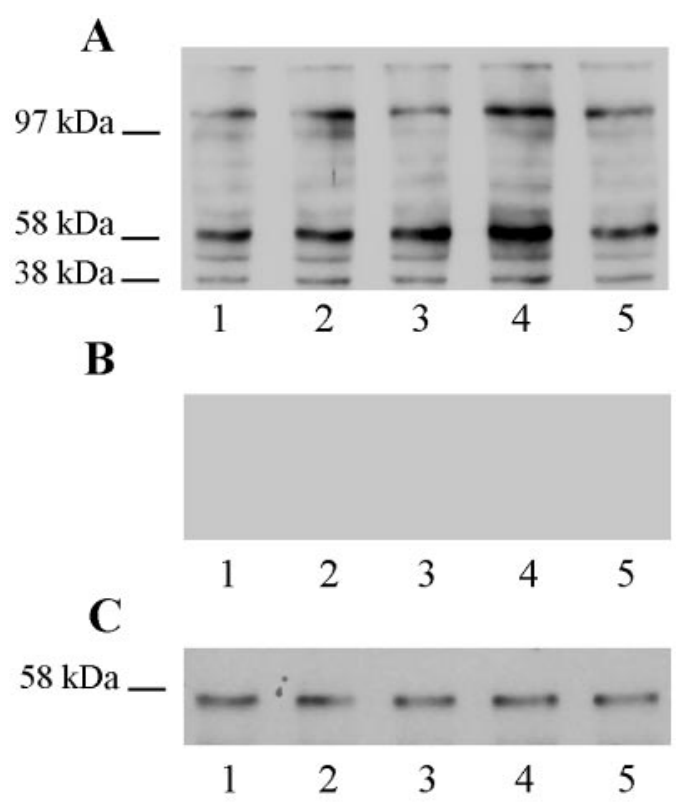

D

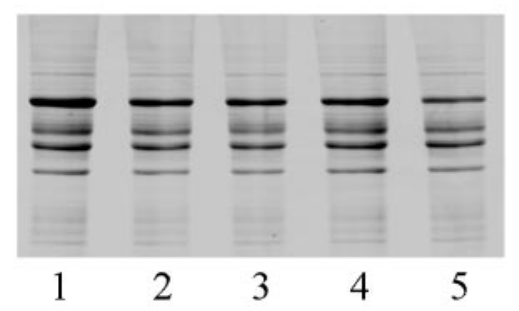

Figure 4. Full-length $\mathrm{A} \beta$ induces tyrosine phosphorylation of neuronal proteins. Rat primary cortical neurons ( $7 \mathrm{~d}$ in culture) were treated with $10 \mu \mathrm{M} \mathrm{A} \beta_{1-42}$ as follows: lane 1, control (no $\left.\mathrm{A} \beta_{1-42}\right)$; lane 2, $1 \mathrm{~min}$; lane 3, $2 \mathrm{~min}$; lane 4, $5 \mathrm{~min}$; lane 5, $10 \mathrm{~min}$. $A$, Whole-cell lysates were prepared, and the Western blot was probed with anti-phosphotyrosine antibody 4G10. $B$, An identically loaded gel was blotted and subsequently treated with SHP-1 protein tyrosine phosphatase before probing with antiphosphotyrosine antibody $4 \mathrm{G} 10$. $C$, Blot from $B$ was stripped and reprobed with mAb PHF-1. $D$, An identically loaded Coomassie-stained gel. Apparent molecular mass $(k D a)$ markers are indicated to the left.

with SHP-1 completely abolished the 4G10 signals for both control and $\mathrm{A} \beta_{1-42}$-treated samples (Fig. $4 B$ ). Subsequent stripping and reprobing of the blot with the mAb PHF-1, which detects tau phosphorylated at its serine 396 and serine 404 residues, revealed a band at $\sim 56 \mathrm{kDa}$ (Fig. $4 C$ ). This confirmed that the $4 \mathrm{G} 10$ immunoreactivity reflected neuronal protein tyrosine phosphorylation and was not caused by protein phosphorylation on other residues or nonspecific reactivity. Figure $4 D$ shows an identically loaded Coomassie-stained gel, demonstrating equal protein loading.

To identify some of the proteins that exhibited increased tyrosine phosphorylation, heat-stable fractions from the cultures were analyzed because selected proteins are easily enriched by heat treatment, including tau, which is important in Alzheimer's disease and has previously been shown to be tyrosine phosphorylated under certain experimental conditions (Lee et al., 1998). Western blots with $4 \mathrm{G} 10$ of heat-stable fractions from control and $\mathrm{A} \beta_{25-35}$-treated rat and human primary neuronal cultures resulted in very similar patterns of labeled proteins (Fig. 5A). Control cultures had essentially a single strong band of apparent molecular mass $77 \mathrm{kDa}$, with weakly labeled material of slightly lower mobility (lanes 1 and 4 ). $\mathrm{A} \beta_{25-35}$ treatment of both rat and 
A
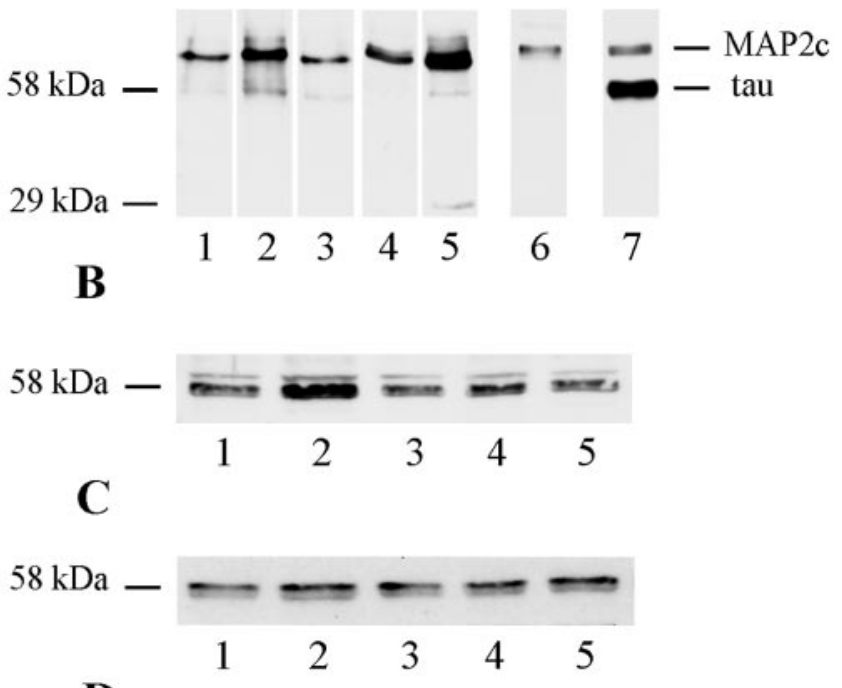

D

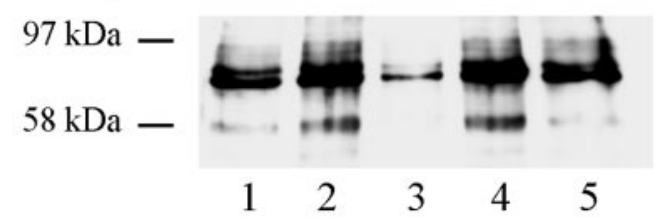

Figure 5. $\mathrm{A} \beta$-induced tyrosine phosphorylation of cytoskeletal proteins. $A$, Heat-stable extracts of 7-d-old rat and 14-d-old human primary neuronal cultures were prepared after treatments as described below and probed with 4G10 (lanes 1-5). Lanes 1-3, Rat primary neuronal cultures ( $7 \mathrm{~d}$ in culture) were either untreated (lane 1, untreated control) or treated for 5 min with $10 \mu \mathrm{M} \mathrm{A} \beta_{25-35}$ (lane 2) or with $10 \mu \mathrm{M} \mathrm{A} \beta_{35-25}$ (lane 3, reverse-sequence control). Lanes $4-5$, Human primary cultures (14 d in culture) were either untreated (lane 4 ) or treated for 5 min with $10 \mu \mathrm{M}$ $\mathrm{A} \beta_{25-35}$ (lane 5). Untreated control rat lysates were also probed with the anti-MAP2 antibody HM-2 (lane 6) or the anti-tau antibody TP70, which also reacts with MAP2c as well as with tau (lane 7). B, C, Western blots of total cell lysates from 14-d-old human primary cortical cultures treated with $10 \mu \mathrm{M} \mathrm{A} \beta_{25-35}$ as follows: lane 1, untreated control; lane 2, $1 \mathrm{~min}$; lane 3, $2 \mathrm{~min}$; lane 4, $5 \mathrm{~min}$; lane $5,10 \mathrm{~min}$. $B$ was probed with the polyclonal antibody $121-3$ specific to tau in which tyrosine 29 is phosphorylated; $C$ was probed with the polyclonal antibody TP70 to total tau. $D$, Western blot with $4 \mathrm{G} 10$ of heat-stable preparations from control 7-d-old primary rat brain cortical cultures (lane 1) or cultures treated with $\mathrm{A} \beta_{25-35}$ alone for $5 \mathrm{~min}$ (lane 2), $\mathrm{A} \beta_{25-35}$ for $5 \mathrm{~min}$ in culture pretreated with the Src-family kinase inhibitor PP2 (lane 3), $\mathrm{A} \beta_{25-35}$ for 5 min in culture pretreated with the protein kinase $\mathrm{C}$ inhibitor bis-indolylmaleimide (lane 4 ), and $\mathrm{A} \beta_{25-35}$ for 5 min in culture pretreated with the PI3-kinase inhibitor wortmannin for $15 \mathrm{~min}$ (lane 5). Apparent molecular mass $(\mathrm{kDa})$ markers are indicated to the left. Bands labeled MAP2c and tau in $A$ had an interpolated molecular mass of 77 and $58 \mathrm{kDa}$, respectively.

human cultures resulted in a marked increase in intensity of labeling of this $77 \mathrm{kDa}$ band and the appearance of a second band at $\sim 58 \mathrm{kDa}$ (lanes 2 and 5). $\mathrm{A} \beta_{25-35}$ treatment of human but not rat neurons also resulted in the appearance of a band at $\sim 29 \mathrm{kDa}$ (lane 5). These were the only 4G10-immunoreactive species reproducibly observed in the heat-stable fractions from the cultures. 4 G10 Western blots of the reverse sequence $\mathrm{A} \beta_{35-25}$-treated cultures were indistinguishable from control cultures, demonstrating that the response was specific for the neurotoxic peptide (rat cultures treated with $\mathrm{A} \beta_{35-25}$, lane 3; treatment of human cells with $\mathrm{A} \beta_{35-25}$ not shown). Similar results were obtained using the polyclonal antibody PY20, which also detects phosphotyrosine residues (data not shown).
Western blots of the heat-stable fractions were probed with monoclonal antibody to MAP2, HM-2, and the polyclonal antibody to tau, TP70. The $77 \mathrm{kDa}$ species was labeled by HM-2 (Fig. $5 A$, lane 6 ), suggesting that this material is most likely MAP2c, and the $58 \mathrm{kDa}$ species was labeled by TP70, again suggesting that it is tau (Fig. 5A, lane 7 ). TP70 was raised against a synthetic $\mathrm{C}$-terminal peptide of tau that shares sequence homology with the $\mathrm{C}$ terminus of MAP2c and has previously been shown to recognize both tau and MAP2c (Brion et al., 1993a), hence the labeling of both bands by TP70 in Figure $5 A$ (lane 7 ). Thus, the fact that this $77 \mathrm{kDa}$ species is heat stable and labeled by two antibodies that recognize MAP2c strongly suggests that it is identical with MAP2c, although we cannot formally rule out another phosphotyrosine-containing protein comigrating at this point. Densitometric analysis of the Western blots showed that $\mathrm{A} \beta$ treatment gave maximum increases in the phosphotyrosine content of approximately fivefold for the putative MAP2c and fourfold for tau.

To confirm that the increase in phosphotyrosine content of the $58 \mathrm{kDa}$ species is indeed caused by an increase in phosphotyrosine content of tau, Western blots of total cell lysates from control untreated and $\mathrm{A} \beta$-treated primary human brain cortical cultures were probed with the phosphotyrosine tau-specific $\mathrm{pAb}$ 121-3, which revealed that the increase in the phosphotyrosine labeling of the $58 \mathrm{kDa}$ species was caused by an increased phosphotyrosine content of tau (Fig. $5 B$ ). The response in this experiment was both rapid and transient, peaking at 1 min after exposure. The increase in tyrosine phosphorylation of tau was specific to $A \beta$ treatment and was not caused by an increase in the overall levels of tau as demonstrated by TP70 labeling (Fig. $5 C$ ). Thus, the increase in labeling by $4 \mathrm{G} 10$ of the band migrating in the position of tau is clearly attributable to a genuine increase in the phosphotyrosine content of tau and not to some other protein comigrating with tau, because the polyclonal antibody $121-3$ is specific to phosphorylated tyrosine 29 within the human tau sequence.

\section{Src family PTKs are involved in $\mathbf{A} \boldsymbol{\beta}$-induced increases in protein phosphotyrosine content}

The compound PP2 inhibits members of the Src family of PTKs such as Src and Fyn. Cultures of primary rat neurons were pretreated with $10 \mu \mathrm{M}$ PP2 for $18 \mathrm{hr}$ before exposure to $\mathrm{A} \beta_{25-35}$, and heat-stable proteins were probed with $4 \mathrm{G} 10$. Figure $5 D$ shows that PP2 pretreatment completely prevented the rapid increase in phosphotyrosine content of tau and putative MAP2c in response to exposure to $\mathrm{A} \beta_{25-35}$ (lanes 1 and 3 ). It is also apparent that pretreatment of cultures with PP2 reduces the basal levels of tyrosine phosphorylation of both cytoskeletal proteins (compare lane 3 with lane 1). Pretreatment of these rat cortical cultures with the protein kinase $\mathrm{C}(\mathrm{PKC})$ inhibitor bis-indolylmaleimide before treatment with $\mathrm{A} \beta_{25-35}$ had no effect on the phosphotyrosine content of tau and putative MAP2c (compare lane 2 with lane 4). However, pretreatment with wortmannin, which selectively inhibits PI3-kinase, before treatment with $\mathrm{A} \beta_{25-35}$ essentially abolished the increase in phosphotyrosine content of both cytoskeletal proteins induced by $\mathrm{A} \beta_{25-35}$ treatment (compare lanes 1, 2, and 5). The effects are most noticeable for tau because the blots are overexposed to detect changes in tau labeling, and hence changes in the putative MAP2c are less obvious.

\section{PHF-tau is tyrosine phosphorylated}

Because $\mathrm{A} \beta$ treatment of neurons in culture clearly resulted in an increase in tyrosine phosphorylation of tau, we reexamined PHF- 
A

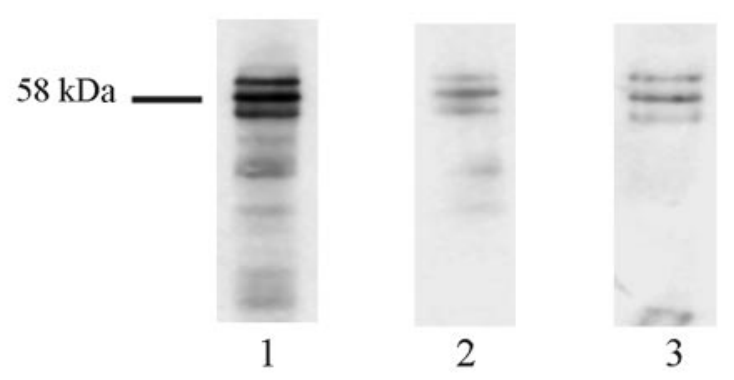

B

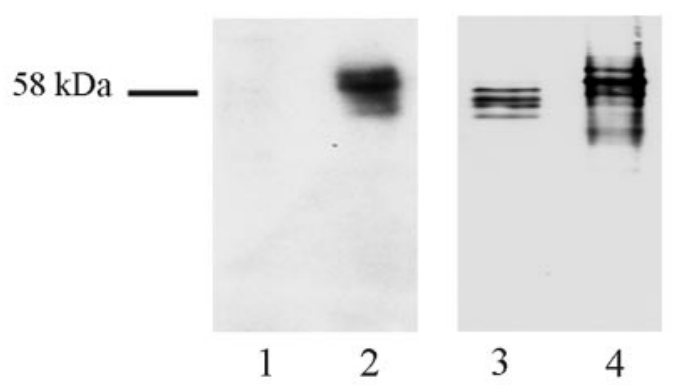

Figure 6. PHF-tau is tyrosine phosphorylated. $A$, Western blots of partially purified PHF-tau isolated from AD brain probed with TP70 (lane 1), PHF-1 (lane 2), 4G10 (lane 3). B, Western blot of tau extracted from a control (non-AD brain; lanes 1 and 3 ) and an AD brain (lanes 2 and 4 ) probed with polyclonal antibody 121-3 (lanes 1 and 2) and with TP70 (lane 3 and 4$)$. Apparent molecular mass $(k D a)$ marker is indicated to the left.

tau isolated from AD brain for evidence of tyrosine phosphorylation. Partially purified PHF-tau from selected cases was labeled on Western blots by $4 \mathrm{G} 10$ in a pattern that was identical to labeling with the polyclonal tau antibody TP70 and monoclonal antibody PHF-1 (Fig. $6 A$ ). The labeling by 4 G10 was weaker than PHF-1, and it was found to be necessary to enrich for PHF-tau to observe clear labeling by 4G10, suggesting that the phosphotyrosine content is lower than the level of phosphorylation at the PHF-1 epitope (serines 396 and 404) (Otvos et al., 1994). Figure $6 B$ confirms that the labeling of PHF-tau by $4 \mathrm{G} 10$ is the result of a portion of PHF-tau containing tyrosine in a phosphorylated state because at least two of the PHF-tau bands were labeled by $\mathrm{pAb} 121-3$. The difference in pattern between 4G10 and pAb 121-3 may be because not all species of PHF-tau contain the same levels of $\mathrm{Tyr}_{29}$ in a phosphorylated state and the tyrosine residues probably also exist in a dephosphorylated state.

Furthermore, tau extracted from neurologically unimpaired individuals is not labeled by the pAb 121-3. We have not observed labeling of tau from control postmortem human brain by $4 \mathrm{G} 10$, and we were unable to label adult rat brain tau with $4 \mathrm{G} 10$, even after the brain was immediately immersed in liquid nitrogen and the tau extracted in buffers containing phosphatase inhibitors. However, tau from neuronal cultures, which is equivalent to fetal brain tau, is weakly labeled by 4G10 (Fig. 5D, lane 1).

\section{$A \beta$ induces association of FAK with Fyn and increased tyrosine phosphorylation of FAK}

Because $A \beta$ is applied externally to neurons in paradigms of $A \beta$ neurotoxicity, it is reasonable to assume that it stimulates intracellular PTKs via a plasma membrane receptor and signaling complex. It has previously been reported that $\mathrm{A} \beta$ treatment of a neuroblastoma cell line (rat CNS B103 neuroblastoma cells)
A

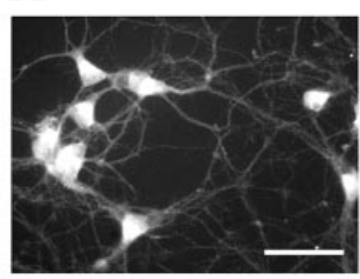

B

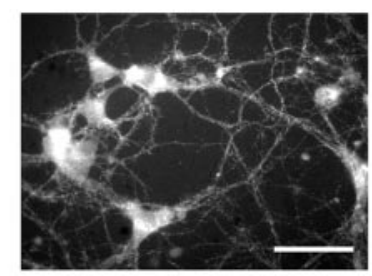

C IP-Fyn: anti-Fyn
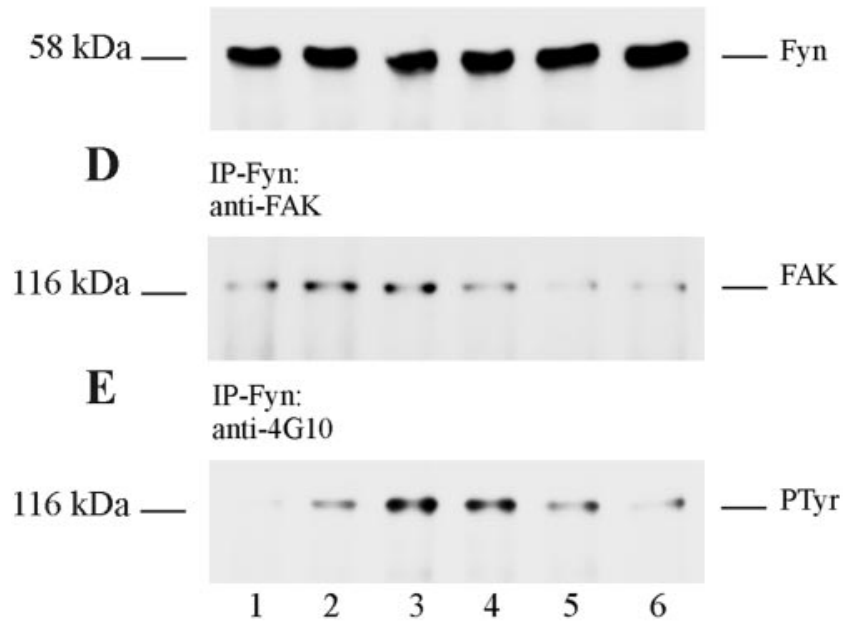

Figure 7. $\mathrm{A} \beta$ induces FAK/Fyn association with increased tyrosine phosphorylation of FAK. Double immunolabeling of 7-d-old primary rat brain cortical cultures with the polyclonal antibody FAK $(A)$ and the monoclonal antibody to Fyn $(B)$. Scale bars, $50 \mu \mathrm{M}$. $C-E$, Western blots of protein lysates immunoprecipitated with anti-Fyn polyclonal antibody from control 7-d-old primary rat cortical cultures (lane 1) and cultures treated with $\mathrm{A} \beta_{25-35}(10 \mu \mathrm{M})$ for $1 \mathrm{~min}$ (lane 2), $2 \mathrm{~min}$ (lane 3), $5 \mathrm{~min}$ (lane 4), 10 min (lane 5), or treated with $\mathrm{A} \beta_{35-25}(10 \mu \mathrm{M})$ for 5 min (lane 6$)$. $C$ was probed with the polyclonal antibody Fyn. $D$ was probed with the polyclonal antibody FAK. $E$ was probed with the monoclonal antibody $4 \mathrm{G} 10$ to phosphotyrosine. Apparent molecular mass $(k D a)$ is indicated on the left.

resulted in an increased level of FAK tyrosine phosphorylation, but only after $48 \mathrm{hr}$ of $\mathrm{A} \beta$ treatment (Zhang et al., 1994). A related non-receptor tyrosine kinase PYK2 has also been reported to phosphorylate tyrosine on proteins in response to $\mathrm{A} \beta$ in microglial cells (Combs et al., 1999). Because PP2, an inhibitor of the Src family of non-receptor tyrosine kinases, blocked $\mathrm{A} \beta$ induced tyrosine phosphorylation of tau and the putative MAP2c (Fig. 5D), we investigated the potential involvement of FAK, PYK2, Fyn, and Src in the rapid changes in neuronal protein phosphotyrosine content.

Double-immunofluorescent labeling showed that primary rat neuronal cultures express both FAK and Fyn and that both FAK and Fyn can be found in the same neuronal compartments, i.e., perikarya and the neuritic network (Fig. $7 A, B$ ). Total cell lysates of primary rat cortical cultures contained both Src and Fyn, and the levels of these proteins as assessed by Western blot of total cell lysates did not change after exposure to $A \beta$ (data not shown). Neurons were left untreated or were exposed to $A \beta_{25-35}$ or the reverse sequence $\mathrm{A} \beta_{35-25}$ and harvested at different times after exposure in RIPA buffer. Proteins were immunoprecipitated with polyclonal antibodies to either Fyn or Src. The immunoprecipi- 
tates were probed on Western blots using $4 \mathrm{G} 10$ or antibodies to FAK, Fyn, or Src. There was no difference in the amount of Fyn immunoprecipitated after the different treatments (Fig. 7C), and it was found that FAK in control neurons (untreated) coprecipitated with Fyn, and exposure to $\mathrm{A} \beta_{25-35}$ resulted in an increase in the amount of FAK associated with Fyn (Fig. 7D). The FAK that was complexed with Fyn from untreated neurons was very weakly tyrosine phosphorylated, but exposure of neurons to $A \beta_{25-35}$ resulted in a marked increase in phosphotyrosine content of FAK, indicative of an activation of FAK (Fig. 7E). The reverse sequence $A \beta_{35-25}$ did not result in a similar activation of FAK (Fig. 7E, lane 6). No association between $\mathrm{Src}$ and FAK was observed in either untreated or treated cells (data not shown), and no evidence for the expression of PYK2 was found in our neuronal cultures (data not shown). Kinase assays of Fyn immunoprecipitated from $\mathrm{A} \beta_{25-35}$-treated primary neuronal cultures revealed a high level of kinase activity in both $\mathrm{A} \beta_{25-35}$-treated and control untreated cultures, suggesting that $\mathrm{A} \beta$ treatment does not result in an increase in activation of total Fyn kinase; rather it results in a relocalization of active Fyn to FAK.

The above experiments showed that the FAK that is associated with Fyn is also tyrosine phosphorylated specifically in response to $\mathrm{A} \beta_{25-35}$ treatment. To determine whether the increased tyrosine phosphorylation of FAK represented a significant fraction of the total cellular FAK, immunoprecipitation of FAK from both rat and human neuronal cultures was performed. Figure $8, A$ and $B$, show that indeed there was a marked increase in tyrosine phosphorylation of total cellular FAK in response to $\mathrm{A} \beta_{25-35}$ treatment of rat and human neurons, respectively. The kinetics of FAK activation appeared to be similar in rat and human neurons, although there was apparently a slightly longer delay to peak activation in human neurons (Fig. $8 B$ ) compared with rat (Fig. $8 A$ ). The peak level of $4 \mathrm{G} 10$ labeling indicated a four- to fivefold increase in FAK tyrosine phosphorylation in both rat and human neurons. The levels of immunoprecipitated FAK protein remained constant during the course of $\mathrm{A} \beta_{25-35}$ exposure (data not shown). The increased tyrosine phosphorylation of FAK was also observed after treatment of rat neurons with full-length $\mathrm{A} \beta_{1-42}$ (Fig. $8 C$ ), and thus, like the increase in content of phosphotyrosine of numerous neuronal proteins (Fig. 3), the signaling responses are also not restricted to the shorter neurotoxic peptide.

\section{$A \beta$-induced FAK activation involves PI3-kinase and Fyn but not PKC}

Cellular responses of neurons to $\mathrm{A} \beta$ treatment have implicated activation of a number of protein kinases. Physiological levels of $\mathrm{A} \beta$ (1 nM) have been reported to activate PI3-kinase through a tyrosine signaling cascade (Luo et al., 1996). A $\beta$ has also been found to activate the MAP kinase pathway, and lithium has been shown to protect against the toxic effect of $\mathrm{A} \beta$, which indicates the involvement of GSK-3 $\beta$ in cell death (Luo et al., 1997; G. Alvarez et al., 1999; Wei et al., 2000). To determine which, if any, of these pathways acts on FAK tyrosine phosphorylation, the cultures were either left untreated or pretreated with LY 294002, PD 98059, bis-indolylmaleimide, lithium chloride, or PP2 before exposure to $A \beta_{25-35}$ for $5 \mathrm{~min}$. The cells were then lysed on ice in RIPA buffer, and the lysates were immunoprecipitated with the polyclonal antibody anti-FAK. Immunoprecipitates were separated by SDS-PAGE and probed on Western blots using the monoclonal antibody $4 \mathrm{G} 10$, to detect tyrosine-phosphorylated FAK, or a polyclonal FAK antibody, to detect total FAK. Glu-
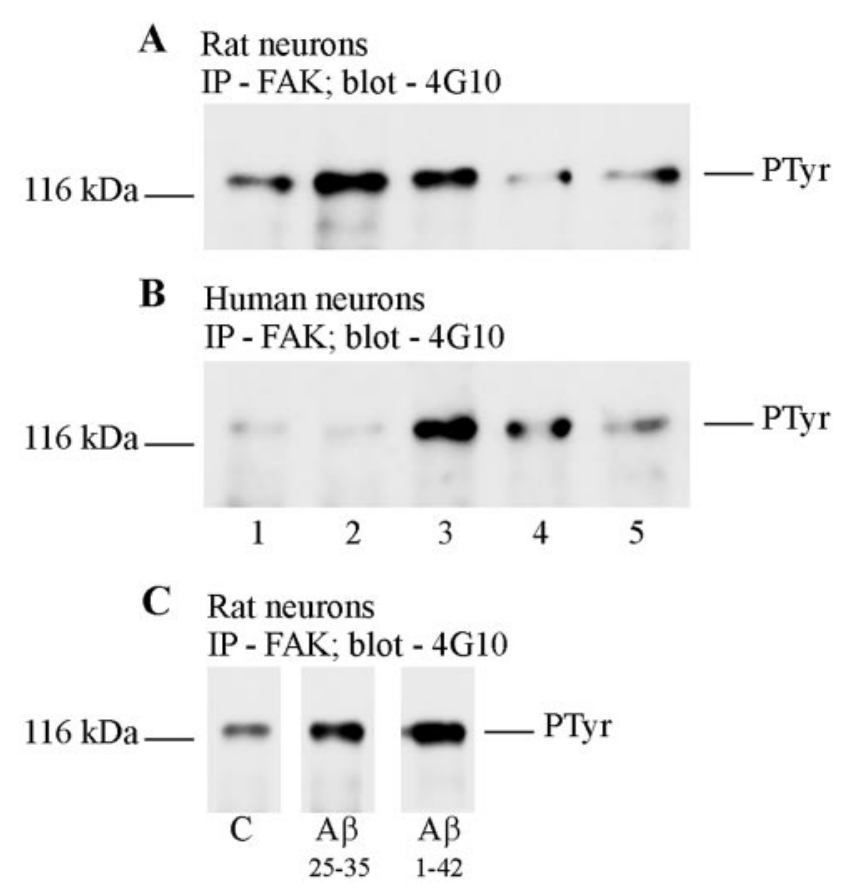

Figure 8. The rate of $\mathrm{A} \beta$-induced FAK activation is similar in primary rat brain cortical cultures and primary human brain cortical cultures. $A, B$, Western blots with $4 \mathrm{G} 10$ of protein immunoprecipitated with anti-FAK polyclonal antibody from cell lysates of 7-d-old primary rat cortical cultures $(A)$ and of 14-d-old human cortical cultures $(B)$. Shown are untreated cultures (lane 1) and cultures treated with $\mathrm{A} \beta_{25-35}(10 \mu \mathrm{M})$ for $1 \mathrm{~min}$ (lane 2), $2 \mathrm{~min}$ (lane 3), $5 \mathrm{~min}$ (lane 4), and $10 \mathrm{~min}$ (lane 5). $C$, Western blot with 4 G10 of protein immunoprecipitated with anti-FAK polyclonal antibody from cell lysates of control 7-d-old primary rat cortical cultures left untreated or treated for 5 min with $10 \mu \mathrm{M} \mathrm{A} \beta_{25-35}$ or 10 $\mu \mathrm{M} \mathrm{A} \beta_{1-42}$ as indicated. Apparent molecular mass $(k D a)$ is indicated on the left.

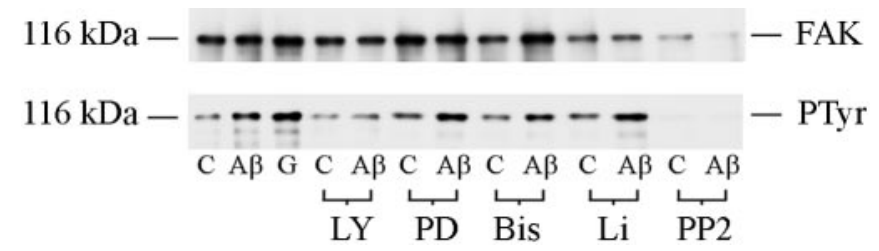

Figure 9. PI3-kinase and Fyn are involved in $\mathrm{A} \beta$-induced FAK activation. Shown are Western blots with 4G10 (bottom panel) and polyclonal antibody to FAK (top panel) of protein immunoprecipitated with antiFAK polyclonal antibody from cell lysates of 7-d-old primary rat brain cortical cultures. Cultures that had been pretreated with LY 294002 (LY), PD $98059(P D)$, bis-indolylmaleimide (Bis), lithium $(L i)$, or PP2 or left untreated as outlined in Materials and Methods were either harvested without further treatment $(C)$ or treated with $\mathrm{A} \beta_{25-35}(10 \mu \mathrm{M})$ for $5 \mathrm{~min}$ $(A \beta)$; a further culture was treated with glutamate $(1 \mathrm{~mm})$ alone for $1 \mathrm{hr}$ $(G)$. Apparent molecular mass $(k D a)$ is indicated on the left.

tamate, which has previously been reported to activate FAK and is toxic to neurons, was also tested in addition as a positive control (Siciliano et al., 1996).

Figure 9 (bottom panel) shows that FAK in untreated neurons (control) was modestly tyrosine phosphorylated, but that FAK in cultures treated with $A \beta_{25-35}$ or glutamate displayed an increased phosphotyrosine content. Pretreatment with LY 294002 or PP2 prevented the $\mathrm{A} \beta$-stimulated increase in FAK tyrosine phosphorylation. PD 98059 and lithium chloride failed to prevent the $\mathrm{A} \beta$-stimulated increase in FAK tyrosine phosphorylation over 
untreated levels, suggesting that any activation of MAP kinase or GSK-3 by A $\beta$ occurs downstream of FAK signaling or through an independent pathway. The inability of bis-indolylmaleimide to inhibit $\mathrm{A} \beta$-stimulated FAK phosphorylation suggests that FAK activation under these conditions is not a PKC-dependent mechanism, in contrast to FAK activation in response to glutamate or acetylcholine (Slack, 1998; Tang et al., 1999). Figure 9 (top panel) shows that the increases in tyrosine phosphorylation observed under the different conditions was not caused by an increase in the levels of FAK that were immunoprecipitated. The ability of both LY 294002 and PP2 to prevent the A $\beta$-induced FAK phosphorylation suggests that both Fyn and PI3-kinase may be involved in FAK activation. Both Fyn and PI3-kinase can associate with FAK through their $\mathrm{SH} 2$ domains when FAK is phosphorylated at its autophosphorylation site, $\operatorname{Tyr}^{397}$ (Cobb et al., 1994; Chen et al., 1996). The ability of LY 294002 to prevent the A $\beta$-stimulated increase in FAK tyrosine phosphorylation suggests that both PI3-kinase and Fyn may be involved in FAK activation, either through direct binding of their SH2 domains to FAK or through SH3 domain interactions between PI3-kinase and Fyn (Renzoni et al., 1996; Wellbrock and Schartl, 2000). In addition, pretreatment of cultures with the calcium chelator EGTA failed to prevent the $\mathrm{A} \beta$-induced FAK tyrosine phosphorylation (data not shown).

\section{Inhibitors of FAK tyrosine phosphorylation prevent $A \beta$-induced ERK2 activation in primary neuronal cultures}

It has previously been reported that $\mathrm{A} \beta$ can stimulate the MAP kinase signaling pathway involving activation of ERK1 and ERK2. Because FAK in certain cellular systems has been reported to be upstream of MAP kinase, we investigated the possibility that ERK1 and ERK2 activation in response to $\mathrm{A} \beta_{25-35}$ treatment is also induced by FAK in neurons. Western blots of rat neuronal cultures with a non-phosphorylation-dependent monoclonal antibody to ERK1 and ERK2 showed that the majority of MAP kinase was represented by ERK2 (Fig. 10 A, top panel). Treatment of rat neuronal cultures with $\mathrm{A} \beta_{25-35}$ for 5-60 min caused a sustained increase in the activation of ERK2 as detected by monoclonal antibodies to the dually phosphorylated threonine202 and tyrosine-204 epitope (Fig. 10A, lane 2-5). No activation of ERK1 was detected, albeit the level of ERK1 was much lower than ERK2. Pretreatment of cultures with the compounds PD 98059 (Fig. 10A, lanes 8 and 9) or LY 294002 (lanes 10 and 11) and harvesting without further treatment or with subsequent exposure to $A \beta_{25-35}$ for 5 min prevented any $A \beta$-induced increase in ERK2 activity without affecting the total ERK protein levels. Pretreatment with PP2 for $18 \mathrm{hr}$ apparently reduced the total levels of ERK protein (Fig. 10A, lanes 6 and 7) and also inhibited $\mathrm{A} \beta$-induced ERK2 activation by $50 \%$ (lane 7 ). Figure $10 B$ shows the relative amounts of active ERK found in each sample. Taken together, the results suggest that $\mathrm{A} \beta$ activates ERK2 in a MEKdependent manner and that ERK activation is downstream of FAK tyrosine phosphorylation and PI3-kinase and Fyn.

\section{DISCUSSION}

The importance of $\mathrm{A} \beta$ deposition in the brain in $\mathrm{AD}$ is strongly implicated from genetic studies. All three genes, $\beta$-amyloid precursor protein, presenilin 1 , and presenilin 2 , now known to cause $\mathrm{AD}$ have been shown to cause an increase in $\mathrm{A} \beta$ production or an increase in the ratio of $\mathrm{A} \beta_{42} / \mathrm{A} \beta_{40}$, both of which drive aggregation (Scheuner et al., 1996; Citron et al., 1997). Possession of one

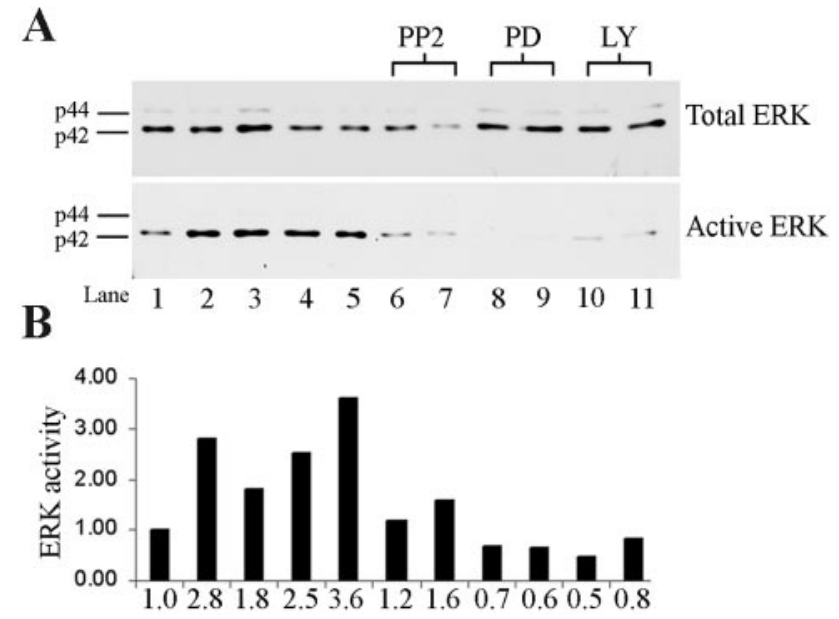

Figure 10. A $\beta$-induced ERK phosphorylation is downstream of FAK activation. $A$, Western blots of RIPA buffer lysates from control 7-d-old primary rat cortical cultures (lane 1) and cultures treated with $\mathrm{A} \beta(10 \mu \mathrm{M})$ and harvested after $5 \mathrm{~min}$ (lane 2), $10 \mathrm{~min}$ (lane 3), $30 \mathrm{~min}$ (lane 4), $60 \mathrm{~min}$ (lane 5), with PP2 alone $(30 \mu \mathrm{M})$ for $18 \mathrm{hr}$ (lane 6), $\mathrm{A} \beta_{25-35}$ for $5 \mathrm{~min}$ in culture pretreated with PP2 (lane 7), PD 98059 alone (lane 8), A $\beta_{25-35}$ for 5 min in culture pretreated with PD 98059 (lane 9), LY 294002 alone (lane 10), and $A \beta_{25-35}$ for 5 min in culture pretreated with LY 294002 (lane 11). Top panel blot was probed with monoclonal antibody MK12 to ERK; bottom panel blot was probed with a monoclonal antibody E10 to phosphorylated ERK1 ( $p 44)$ and ERK2 (p42). B, Quantification of ERK kinase phosphorylation of the experiments shown in $A$. The activity, as indicated numerically beneath the abscissa, is expressed relative to the control $(0 \mathrm{~min})$ that was normalized to 1 .

or two $\mathrm{E} 4$ alleles of apolipoprotein $\mathrm{E}$ also results in increased $\mathrm{A} \beta$ deposition in the brain before clinical symptoms arise (Polvikoski et al., 1995). It is now generally accepted that deposition of diffuse deposits of $\mathrm{A} \beta$ in the brain is an early event in the development of $\mathrm{AD}$, and neurotoxicity of $\mathrm{A} \beta$ is well established in in vitro models. There is still a lack of agreement on the physical nature of the neurotoxic form of $\mathrm{A} \beta$, but fibrils reproducibly damage cultured neurons, although the mechanisms leading to cell death are not established and reports are often contradictory (Abe and Saito, 2000; Marin et al., 2000; Troy et al., 2000). The early deposition of $\mathrm{A} \beta$ in the pathogenic sequence emphasizes the importance of elucidating the initial response of neurons to $\mathrm{A} \beta$ fibrils.

Here we confirm that $A \beta$-derived neurotoxicity in culture is slow, in agreement with earlier observations (Behl et al., 1994; Estus et al., 1997; Abe and Saito, 2000; Greeve et al., 2000). Cell death could not be detected before $24 \mathrm{hr}$, with a rise in caspase activity concomitant with $\mathrm{LDH}$ release and with complete cell death in cultures occurring slowly over $96 \mathrm{hr}$. This is similar to reported glutamate-induced excitotoxic mechanisms, in which a marked increase in LDH release in response to glutamate was measured only after 18-24 hr (Gray and Patel, 1995). However, glutamate does induce early and irreversible changes before cell death, in particular $\mathrm{Ca}^{2+}$ influx (Randall and Thayer, 1992), membrane depolarization, and activation of postsynaptic cell membrane receptors with subsequent opening of ion channels, resulting in a disturbed intracellular ionic environment, which then inevitably results in cell death (Rothstein, 1996). We therefore looked for early responses to $\mathrm{A} \beta$ because they too may be the critical events in neurotoxicity.

Here we report a rapid and somewhat transient rise in tyrosine phosphorylation of cellular and cytoskeletal proteins in response 
to both $\mathrm{A} \beta_{25-35}$ and $\mathrm{A} \beta_{1-42}$. The shorter $\mathrm{A} \beta_{25-35}$ was shown to be more potent than the full-length $\mathrm{A} \beta_{1-42}$ at eliciting an increase in tyrosine phosphorylation, consistent with previously reported findings (Varadarajan et al., 2001). The peak increase in tyrosine phosphorylation was variable, usually being slower in human neuronal cultures, but precise measurement over short times in this type of cellular response is problematic. Calcium ions were not required for the phosphorylation of FAK in response to $\mathrm{A} \beta_{25-35}$. Previous reports of $\mathrm{Ca}^{2+}$ influx in $\mathrm{A} \beta$-induced cell death suggest that parallel pathways may be activated in response to $\mathrm{A} \beta$ (Luo et al., 1995; Ekinci et al., 1999; MacManus et al., 2000). Tyrosine phosphorylation changes often serve to activate downstream serine/threonine kinases. The response involved Fyn but not Src and an activation of FAK and increased association of FAK with Fyn. These changes are similar to activation of FAK and Fyn in other cell signaling systems such as integrin signaling. Other workers have reported tyrosine kinase activation in microglial cultures using higher concentrations of $\mathrm{A} \beta(50 \mu \mathrm{M})$, but we now show that this occurs in neurons in response to $10 \mu \mathrm{M}$ $\mathrm{A} \beta_{25-35}$ (McDonald et al., 1998). Fyn activation is likely to be important in $\mathrm{A} \beta$ neurotoxicity because Fyn knock-out mice are reported to be resistant to ADDL toxicity (Lambert et al., 1998).

MAP kinase has previously been reported to be activated in microglial and THP1 monocyte cultures after administration of high concentrations of $\mathrm{A} \beta$ (Combs et al., 1999); however, the activation was transient. Now we show that ERK activation is rapid and sustained and that this is consistent with it being downstream of FAK association with Fyn. Furthermore, in our neuronal cultures, PI3-kinase appears to be required for ERK activation in response to $\mathrm{A} \beta$ treatment. This is consistent with previously reported studies in which inhibition of PI3-kinase blocked the activation of ERK2 by integrin in fibroblast cell lines (King et al., 1997; Finkelstein and Shimizu, 2000).

Tau has been shown to be tyrosine phosphorylated in COS7 cells doubly transfected with Fyn and tau (Lee et al., 1998). We therefore investigated whether tau is tyrosine phosphorylated in response to $\mathrm{A} \beta$ treatment and found that both tau and most likely MAP2c are tyrosine phosphorylated in neurons and that the kinetics of tyrosine phosphorylation mimic the kinetics of FAK activation and FAK/Fyn complex formation. Furthermore, the ability of PP2 to prevent the A $\beta$-induced tyrosine phosphorylation of tau and MAP2c strongly suggests that tau and MAP2c are indeed substrates of Fyn in the response to $A \beta$. It was therefore important to search for evidence of tyrosine phosphorylation of cytoskeletal proteins in AD brain, and we discovered that PHFtau is indeed tyrosine phosphorylated. On the other hand, we could not demonstrate tyrosine phosphorylation of normal adult brain tau, although fetal brain tau has a low level of tyrosine phosphorylation. Thus, it might be that the tyrosine phosphorylation of PHF-tau is another example of the phosphorylation state mimicking the fetal phosphorylation of tau (Kanemaru et al., 1992; Bramblett et al., 1993; Brion et al., 1993b; Goedert et al., 1993; Watanabe et al., 1993). Further work needs to be done to establish whether this tyrosine phosphorylation may trigger aggregation of tau to produce PHF-tau and whether it influences the phosphorylation of tau by serine/threonine protein kinases. It is also of interest to determine whether all or only some of the tyrosine residues in tau are phosphorylated, and so far using a specific antibody we have shown that tyrosine 29 is phosphorylated in human tau in response to $\mathrm{A} \beta$ exposure and in PHF-tau. However, the difference in the labeling pattern of PHF-tau with this antibody and 4G10 suggests that there may be heterogeneity of tyrosine phosphorylation in PHF-tau. We also had to enrich the PHF-tau fraction to obtain labeling with phosphotyrosinespecific antibodies, and not all cases of AD brain showed evidence of tyrosine phosphorylation of PHF-tau. This may well be attributable to the more labile nature of tyrosine phosphorylation compared with serine and threonine phosphorylation.

FAK levels in the adult brain are found to be at their highest in the cerebral cortex and hippocampus (Burgaya et al., 1995). FAK serves as a regulated adaptor protein, recruiting other proteins by autophosphorylation of its tyrosine ${ }^{397}$ residue, a high-affinity binding site for SH2 domains of Fyn, Src, and PI3-kinase (Chen and Guan, 1994; Cobb et al., 1994; Schaller et al., 1994). Binding of these kinases can in turn enable them to phosphorylate tyrosine residues in the $\mathrm{C}$-terminal region of FAK and also other cytoskeletal proteins associated with FAK. This is followed by recruitment of other proteins, resulting in the formation of large multimolecular structures capable of triggering a number of different signaling pathways.

The rapid changes reported here of FAK and Fyn association with increased tyrosine phosphorylation of FAK, with ERK activation, and elevated tyrosine phosphorylation of cytoskeletal proteins, all preceded measurable neuronal death. The activation of Fyn/FAK/PI3-kinase/MAP kinase is associated with protective (anti-apoptotic) signaling systems under normal physiological conditions, and all have been reported to be activated by $\mathrm{A} \beta$ in different cell systems (Klinghoffer et al., 1999; Schaeffer and Weber, 1999; Sonoda et al., 1999; Lee and States, 2000). We suggest that there may be an incomplete mimicking of positive trophic signaling and that the full set of downstream changes are not activated, and hence $\mathrm{A} \beta$ induces an abortive response that then leads to cell death.

The dual role of FAK in normal physiological and pathological processes highlights its importance as a convergence point in divergent signaling pathways. Ultimately the nature and composition of the multimolecular complexes that are formed underly the physiological effects of FAK activation. Increased tyrosine phosphorylation of FAK provides a mechanism by which $\mathrm{A} \beta$ can be coupled to signal transduction pathways exerting a major influence on cell fate decisions. Elucidation of the components of the multimolecular complexes and signaling pathways is an important step in understanding $\mathrm{A} \beta$-induced neuronal toxicity.

\section{REFERENCES}

Abe K, Saito H (2000) Amyloid beta neurotoxicity not mediated by the mitogen-activated protein kinase cascade in cultured rat hippocampal and cortical neurons. Neurosci Lett 292:1-4.

Alvarez A, Toro R, Caceres A, Maccioni RB (1999) Inhibition of tau phosphorylating protein kinase cdk5 prevents beta-amyloid-induced neuronal death. FEBS Lett 459:421-426.

Alvarez G, Munoz-Montano JR, Satrustegui J, Avila J, Bogonez E, Diaz-Nido J (1999) Lithium protects cultured neurons against betaamyloid-induced neurodegeneration. FEBS Lett 453:260-264.

Behl C, Davis JB, Lesley R, Schubert D (1994) Hydrogen peroxide mediates amyloid beta protein toxicity. Cell 77:817-827.

Bradford MM (1976) A rapid and sensitive method for the quantitation of microgram quantities of protein utilizing the principle of protein-dye binding. Anal Biochem 72:248-254

Bramblett GT, Goedert M, Jakes R, Merrick SE, Trojanowski JQ, Lee VM (1993) Abnormal tau phosphorylation at Ser396 in Alzheimer's disease recapitulates development and contributes to reduced microtubule binding. Neuron 10:1089-1099.

Brion JP, Couck AM, Robertson J, Loviny TL, Anderton BH (1993a) Neurofilament monoclonal antibodies RT97 and 8D8 recognize different modified epitopes in paired helical filament-tau in Alzheimer's disease. J Neurochem 60:1372-1382.

Brion JP, Smith C, Couck AM, Gallo JM, Anderton BH (1993b) Developmental changes in tau phosphorylation: fetal tau is transiently phosphorylated in a manner similar to paired helical filament-tau characteristic of Alzheimer's disease. J Neurochem 61:2071-2080. 
Burgaya F, Menegon A, Menegoz M, Valtorta F, Girault JA (1995) Focal adhesion kinase in rat central nervous system. Eur J Neurosci 7:1810-1821.

Busciglio J, Lorenzo A, Yeh J, Yankner BA (1995) Beta-amyloid fibrils induce tau phosphorylation and loss of microtubule binding. Neuron 14:879-888.

Chen HC, Guan JL (1994) Association of focal adhesion kinase with its potential substrate phosphatidylinositol 3-kinase. Proc Natl Acad Sci USA 91:10148-10152.

Chen HC, Appeddu PA, Isoda H, Guan JL (1996) Phosphorylation of tyrosine 397 in focal adhesion kinase is required for binding phosphatidylinositol 3-kinase. J Biol Chem 271:26329-26334.

Citron M, Westaway D, Xia W, Carlson G, Diehl T, Levesque G, Johnson-Wood K, Lee M, Seubert P, Davis A, Kholodenko D, Motter R, Sherrington R, Perry B, Yao H, Strome R, Lieberburg I, Rommens J, Kim S, Schenk D, Fraser P, St. George HP, Selkoe DJ (1997) Mutant presenilins of Alzheimer's disease increase production of 42residue amyloid beta-protein in both transfected cells and transgenic mice. Nat Med 3:67-72.

Cobb BS, Schaller MD, Leu TH, Parsons JT (1994) Stable association of pp60src and pp59fyn with the focal adhesion-associated protein tyrosine kinase, pp125FAK. Mol Cell Biol 14:147-155.

Combs CK, Johnson DE, Cannady SB, Lehman TM, Landreth GE (1999) Identification of microglial signal transduction pathways mediating a neurotoxic response to amyloidogenic fragments of betaamyloid and prion proteins. J Neurosci 19:928-939.

Davis DR, Brion JP, Couck AM, Gallo JM, Hanger DP, Ladhani K, Lewis C, Miller CC, Rupniak T, Smith C (1995) The phosphorylation state of the microtubule-associated protein tau as affected by glutamate, colchicine and beta-amyloid in primary rat cortical neuronal cultures. Biochem J 309:941-949.

Ekinci FJ, Malik KU, Shea TB (1999) Activation of the L voltagesensitive calcium channel by mitogen-activated protein (MAP) kinase following exposure of neuronal cells to beta-amyloid. MAP kinase mediates beta-amyloid-induced neurodegeneration. J Biol Chem 274:30322-30327.

Ekinci FJ, Linsley MD, Shea TB (2000) Beta-amyloid-induced calcium influx induces apoptosis in culture by oxidative stress rather than tau phosphorylation. Brain Res Mol Brain Res 76:389-395

Estus S, Tucker HM, van Rooyen C, Wright S, Brigham EF, Wogulis M, Rydel RE (1997) Aggregated amyloid-beta protein induces cortical neuronal apoptosis and concomitant "apoptotic" pattern of gene induction. J Neurosci 17:7736-7745.

Finkelstein LD, Shimizu Y (2000) Role of phosphoinositide 3-kinase and the $\mathrm{Cbl}$ adaptor protein in coupling the alpha4beta1 integrin to mitogen-activated protein kinase signalling. Biochem J 345:385-392.

Goedert M, Jakes R, Crowther RA, Six J, Lubke U, Vandermeeren M, Cras P, Trojanowski JQ, Lee VM (1993) The abnormal phosphorylation of tau protein at Ser-202 in Alzheimer disease recapitulates phosphorylation during development. Proc Natl Acad Sci USA 90:5066-5070.

Grant SG, O’Dell TJ, Karl KA, Stein PL, Soriano P, Kandel ER (1992) Impaired long-term potentiation, spatial learning, and hippocampal development in fyn mutant mice. Science 258:1903-1910.

Gray CW, Patel AJ (1995) Neurodegeneration mediated by glutamate and beta-amyloid peptide: a comparison and possible interaction. Brain Res 691:169-179.

Greeve I, Hermans-Borgmeyer I, Brellinger C, Kasper D, Gomez-Isla T, Behl C, Levkau B, Nitsch RM (2000) The human DIMINUTO/ DWARF1 homolog seladin-1 confers resistance to Alzheimer's disease-associated neurodegeneration and oxidative stress. J Neurosci 20:7345-7352.

Hanger DP, Betts JC, Loviny TL, Blackstock WP, Anderton BH (1998) New phosphorylation sites identified in hyperphosphorylated tau (paired helical filament-tau) from Alzheimer's disease brain using nanoelectrospray mass spectrometry. J Neurochem 71:2465-2476.

Harada J, Sugimoto M (1999) Activation of caspase-3 in beta-amyloidinduced apoptosis of cultured rat cortical neurons. Brain Res 842:311-323.

Imahori K, Uchida T (1997) Physiology and pathology of tau protein kinases in relation to Alzheimer's disease. J Biochem (Tokyo) 121:179-188.

Kanemaru K, Takio K, Miura R, Titani K, Ihara Y (1992) Fetal-type phosphorylation of the tau in paired helical filaments. J Neurochem 58:1667-1675

King WG, Mattaliano MD, Chan TO, Tsichlis PN, Brugge JS (1997) Phosphatidylinositol 3-kinase is required for integrin-stimulated AKT and Raf-1/mitogen-activated protein kinase pathway activation. Mol Cell Biol 17:4406-4418.

Klinghoffer RA, Sachsenmaier C, Cooper JA, Soriano P (1999) Src family kinases are required for integrin but not PDGFR signal transduction. EMBO J 18:2459-2471.

Lambert MP, Barlow AK, Chromy BA, Edwards C, Freed R, Liosatos M, Morgan TE, Rozovsky I, Trommer B, Viola KL, Wals P, Zhang C, Finch CE, Krafft GA, Klein WL (1998) Diff usible, nonfibrillar ligands derived from Abeta1-42 are potent central nervous system neurotoxins. Proc Natl Acad Sci USA 95:6448-6453.

Lee AW, States DJ (2000) Both src-dependent and -independent mechanisms mediate phosphatidylinositol 3-kinase regulation of colonystimulating factor 1-activated mitogen-activated protein kinases in myeloid progenitors. Mol Cell Biol 20:6779-6798.

Lee G, Newman ST, Gard DL, Band H, Panchamoorthy G (1998) Tau interacts with src-family non-receptor tyrosine kinases. J Cell Sci 111:3167-3177.

Lee MS, Kwon YT, Li M, Peng J, Friedlander RM, Tsai LH (2000) Neurotoxicity induces cleavage of p35 to p25 by calpain. Nature 405:360-364.

Lesort M, Jope RS, Johnson GV (1999) Insulin transiently increases tau phosphorylation: involvement of glycogen synthase kinase-3beta and Fyn tyrosine kinase. J Neurochem 72:576-584.

Lovestone S, Reynolds CH, Latimer D, Davis DR, Anderton BH, Gallo JM, Hanger D, Mulot S, Marquardt B, Stabel S (1994) Alzheimer's disease-like phosphorylation of the microtubule-associated protein tau by glycogen synthase kinase-3 in transfected mammalian cells. Curr Biol 4:1077-1086.

Luo Y, Sunderland T, Wolozin B (1996) Physiologic levels of betaamyloid activate phosphatidylinositol 3-kinase with the involvement of tyrosine phosphorylation. J Neurochem 67:978-987.

Luo Y, Hawver DB, Iwasaki K, Sunderland T, Roth GS, Wolozin B (1997) Physiological levels of beta-amyloid peptide stimulate protein kinase C in PC12 cells. Brain Res 769:287-295.

Luo YQ, Hirashima N, Li YH, Alkon DL, Sunderland T, Etcheberrigaray R, Wolozin B (1995) Physiological levels of beta-amyloid increase tyrosine phosphorylation and cytosolic calcium. Brain Res 681:65-74.

MacManus A, Ramsden M, Murray M, Henderson Z, Pearson HA, Campbell VA (2000) Enhancement of ${ }^{(45)} \mathrm{Ca}^{(2+)}$ influx and voltagedependent $\mathrm{Ca}(2+)$ channel activity by beta-amyloid-(1-40) in rat cortical synaptosomes and cultured cortical neurons. Modulation by the proinflammatory cytokine interleukin-1beta. J Biol Chem 275:4713-4718.

Marin N, Romero B, Bosch-Morell F, Llansola M, Felipo V, Roma J, Romero FJ (2000) Beta-amyloid-induced activation of caspase-3 in primary cultures of rat neurons. Mech Ageing Dev 119:63-67.

McDonald DR, Bamberger ME, Combs CK, Landreth GE (1998) $\beta$-Amyloid fibrils activate parallel mitogen-activated protein kinase pathways in microglia and THP1 monocytes. J Neurosci 18:4451-4460.

Otvos Jr L, Feiner L, Lang E, Szendrei GI, Goedert M, Lee VM (1994) Monoclonal antibody $\mathrm{PHF}-1$ recognizes tau protein phosphorylated at serine residues 396 and 404. J Neurosci Res 39:669-673.

Polvikoski T, Sulkava R, Haltia M, Kainulainen K, Vuorio A, Verkkoniemi A, Niinisto L, Halonen P, Kontula K (1995) Apolipoprotein E, dementia, and cortical deposition of beta-amyloid protein. $N$ Engl J Med 333:1242-1247.

Pyo H, Jou I, Jung S, Hong S, Joe EH (1998) Mitogen-activated protein kinases activated by lipopolysaccharide and beta-amyloid in cultured rat microglia. NeuroReport 9:871-874.

Randall RD, Thayer SA (1992) Glutamate-induced calcium transient triggers delayed calcium overload and neurotoxicity in rat hippocampal neurons. J Neurosci 12:1882-1895.

Rapoport M, Ferreira A (2000) PD98059 prevents neurite degeneration induced by fibrillar beta-amyloid in mature hippocampal neurons. J Neurochem 74:125-133.

Renzoni DA, Pugh DJ, Siligardi G, Das P, Morton CJ, Rossi C, Waterfield MD, Campbell ID, Ladbury JE (1996) Structural and thermodynamic characterization of the interaction of the SH3 domain from Fyn with the proline-rich binding site on the p85 subunit of PI3-kinase. Biochemistry 35:15646-15653.

Rothstein JD (1996) Excitotoxicity hypothesis. Neurology 47:S19-S25.

Sato N, Kamino K, Tateishi K, Satoh T, Nishiwaki Y, Yoshiiwa A, Miki T, Ogihara T (1997) Elevated amyloid beta protein(1-40) level induces CREB phosphorylation at serine-133 via p44/42 MAP kinase (Erk1/2)-dependent pathway in rat pheochromocytoma PC12 cells. Biochem Biophys Res Commun 232:637-642.

Schaeffer HJ, Weber MJ (1999) Mitogen-activated protein kinases: specific messages from ubiquitous messengers. Mol Cell Biol 19:2435-2444.

Schaller MD, Hildebrand JD, Shannon JD, Fox JW, Vines RR, Parsons JT (1994) Autophosphorylation of the focal adhesion kinase, pp125FAK, directs SH2-dependent binding of pp60src. Mol Cell Biol 14:1680-1688.

Scheuner D, Eckman C, Jensen M, Song X, Citron M, Suzuki N, Bird TD, Hardy J, Hutton M, Kukull W, Larson E, Levy-Lahad E, Viitanen M, Peskind E, Poorkaj P, Schellenberg G, Tanzi R, Wasco W, Lannfelt L, Selkoe D, Younkin S (1996) Secreted amyloid beta-protein similar to that in the senile plaques of Alzheimer's disease is increased in vivo by the presenilin 1 and 2 and APP mutations linked to familial Alzheimer's disease. Nat Med 2:864-870.

Serpell LC (2000) Alzheimer's amyloid fibrils: structure and assembly. Biochim Biophys Acta 1502:16-30. 
Shirazi SK, Wood JG (1993) The protein tyrosine kinase, fyn, in Alzheimer's disease pathology. NeuroReport 4:435-437.

Siciliano JC, Toutant M, Derkinderen P, Sasaki T, Girault JA (1996) Differential regulation of proline-rich tyrosine kinase $2 /$ cell adhesion kinase beta (PYK2/CAKbeta) and pp125(FAK) by glutamate and depolarization in rat hippocampus. J Biol Chem 271:28942-28946.

Slack BE (1998) Tyrosine phosphorylation of paxillin and focal adhesion kinase by activation of muscarinic $\mathrm{m} 3$ receptors is dependent on integrin engagement by the extracellular matrix. Proc Natl Acad Sci USA 95:7281-7286.

Smith C, Anderton BH (1994) Dorothy Russell Memorial Lecture. The molecular pathology of Alzheimer's disease: are we any closer to understanding the neurodegenerative process? Neuropathol Appl Neurobiol 20:322-338.

Sonoda Y, Watanabe S, Matsumoto Y, Aizu-Yokota E, Kasahara T (1999) FAK is the upstream signal protein of the phosphatidylinositol 3-kinase-Akt survival pathway in hydrogen peroxide-induced apoptosis of a human glioblastoma cell line. J Biol Chem 274:10566-10570.

Takashima A, Honda T, Yasutake K, Michel G, Murayama O, Murayama M, Ishiguro K, Yamaguchi H (1998) Activation of tau protein kinase I/glycogen synthase kinase-3beta by amyloid beta peptide (25-35) enhances phosphorylation of tau in hippocampal neurons. Neurosci Res 31:317-323.

Tang D, Mehta D, Gunst SJ (1999) Mechanosensitive tyrosine phosphorylation of paxillin and focal adhesion kinase in tracheal smooth muscle. Am J Physiol 276:C250-C258.
Terzi E, Holzemann G, Seelig J (1994) Reversible random coil-betasheet transition of the Alzheimer beta-amyloid fragment (25-35). Biochemistry 33:1345-1350.

Troy CM, Rabacchi SA, Friedman WJ, Frappier TF, Brown K, Shelanski ML (2000) Caspase-2 mediates neuronal cell death induced by betaamyloid. J Neurosci 20:1386-1392.

Varadarajan S, Kanski J, Aksenova M, Lauderback C, Butterfield DA (2001) Different mechanisms of oxidative stress and neurotoxicity for Alzheimer's abeta(1-42) and abeta(25-35). J Am Chem Soc 123:5625-5631.

Watanabe A, Hasegawa M, Suzuki M, Takio K, Morishima-Kawashima M, Titani K, Arai T, Kosik KS, Ihara Y (1993) In vivo phosphorylation sites in fetal and adult rat tau. J Biol Chem 268:25712-25717.

Wei H, Leeds PR, Qian Y, Wei W, Chen R, Chuang D (2000) Betaamyloid peptide-induced death of PC 12 cells and cerebellar granule cell neurons is inhibited by long-term lithium treatment. Eur J Pharmacol 392:117-123.

Wellbrock C, Schartl M (2000) Activation of phosphatidylinositol 3-kinase by a complex of p59fyn and the receptor tyrosine kinase Xmrk is involved in malignant transformation of pigment cells. Eur J Biochem 267:3513-3522.

Zhang C, Lambert MP, Bunch C, Barber K, Wade WS, Krafft GA, Klein WL (1994) Focal adhesion kinase expressed by nerve cell lines shows increased tyrosine phosphorylation in response to Alzheimer's A beta peptide. J Biol Chem 269:25247-25250. 